\title{
Positive Feedback: The Impact of Trade Liberalization on Industry Demands for Protection
}

\author{
Oona A. Hathaway
}

The continued openness of the U.S. economy during the 1970s and 1980s poses a puzzle for many theories of political economy. Despite the world economic recessions of this period, the influx of cheap goods from Asia, and the increased competitiveness of European firms, demand for protection was much lower than many scholars, particularly interest-group theorists, had predicted. In fact, many U.S. industries that were hurt by these trends actually became less protectionist. Although the use of nontariff barriers increased during the 1970s and 1980s, these trade barriers proved to be less effective in reducing trade than the tariffs they replaced. ${ }^{1}$ Unilateral reductions in U.S. tariffs continued unabated, regional trade agreements blossomed, and the global movement toward multilateral trade liberalization marched steadily forward.

The puzzle raised by the vitality of free trade during this period has prompted considerable debate. To resolve this puzzle, most theorists have focused on supplyside factors that may have offset rising protectionist demand, such as international regimes and well-insulated state actors. ${ }^{2}$ In contrast, very little attention has been paid to changes in societal demand for protection. The central assumption has been that economic actors have largely static preferences for free trade or protection. As a result, the evolution of the preferences and strategies of producers in the face of changes in trade policy has been largely ignored.

To fill this gap I propose a theory of dynamic industry preferences and strategies to explain variation in industries' demand for protection over time. This theory shows

For their helpful comments on the manuscript, I am grateful to Lawrence Broz, Alvin Klevorick, Michael Hiscox, Robert Keohane, Jonathan Crystal, James Alt, Edward Schwartz, Mohan Penubarti, Sara Su Jones, three anonymous $I O$ referees, and the editors of $I O$. I owe the greatest debt to my husband, Jacob S. Hacker, for his intellectual and personal support at every stage of this project.

1. Although there is some disagreement among scholars about the effect of nontariff barriers (NTBs) on world trade, most have concluded that the growth of NTBs has had, "at worst, a moderately adverse effect on the growth of trade." Bhagwati 1988, 56. See, for example, Morici and Megna 1983, 11; Milner 1988, 11-12; and Hansen and Prusa 1995, 311-12.

2. See, for example, Destler 1986; Keohane 1984; Lake 1983; and Krasner 1982. A notable exception to this trend is Milner 1988. 
how the characteristics of industries affect their demand for protection and how, in turn, trade policy transforms industry characteristics. An important and counterintuitive implication of this theory is that trade liberalization tends to reduce, rather than increase, industry demand for protection.

The theory I develop in this article focuses on the determinants of political demand for protection. Although a theory of demand only represents half of the political equation that produces trade policy outcomes, a focus on demand is, nonetheless, critical because the source of industry preferences and strategies is poorly understood. Moreover, to the extent that policymakers respond to industry demands for protection, a dynamic theory of demand can provide important insight into trade policy outcomes.

I begin this article by developing a static model of industry decision making that illustrates how producers faced with a reduction in trade barriers weigh the costs and benefits of political action and economic adjustment. I then explain how the strategic choices of an industry are determined by key industry characteristics that evolve over time in response to changes in trade policy and market conditions. In particular, I demonstrate that reductions in trade barriers may have a positive feedback effect that dampens rather than amplifies domestic protectionist sentiment. To test this model, I examine the dramatic postwar transformation of three industries that have historically demanded and received extensive import protection: the footwear, textile, and apparel industries. I conclude with an assessment of the model and a discussion of its possible implications for our understanding of the politics of trade policy.

\section{A Model of Preference and Strategy Formation}

The model of industry decision making that I develop focuses on the aftermath of a trade barrier reduction (regardless of how it has come about) and explains the impact of that reduction on the future demand for protection by affected industries. ${ }^{3} \mathrm{Al}-$ though the model does not explain why the initial reductions in trade barriers occurand, indeed, treats the supply of protection as completely exogenous-it shows that they may have the counterintuitive effect of decreasing protectionist sentiment by altering the characteristics of affected industries in ways that reduce their demand for protection.

In the model, the industry is the basic unit of analysis, and the producer is the central actor within the industry. I focus on industries because they provide a common framework that shapes the preferences and strategies of producers. Although producers within an industry act independently, many of the factors that determine how a producer will react to a reduction in trade barriers are common to all members of an industry. The industry context also shapes how a producer articulates its prefer-

3. The dynamic model of industry behavior is informed by numerous works that analyze international trade policies in political-economic and game-theoretic terms, especially Krueger 1992, 109-14; Bhagwati 1988; Baldwin 1985; Mayer 1984,970-85; Baldwin 1982, 153-84; Brock and Magee 1980,1-9; and Brock and Magee 1978, 246-50. 


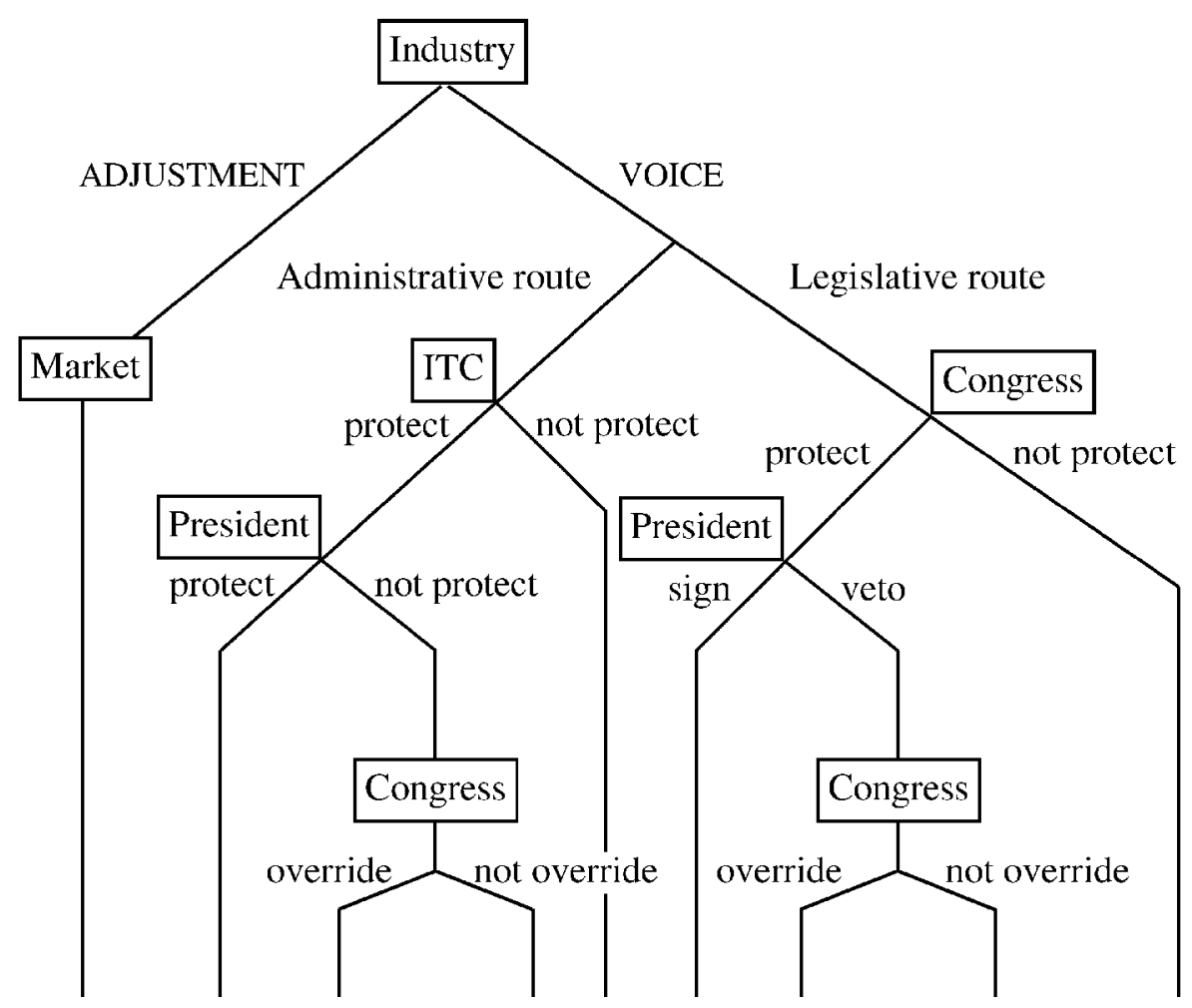

FIGURE 1. A model of industry decision making

ences in the political arena because most producers voice their policy demands through industry associations that aggregate and pursue member preferences. ${ }^{4}$ As a population of firms in an industry changes in response to a reduction in trade barriers-with each individual firm either adjusting to the more competitive environment or exiting the industry - the aggregate of those firms' preferences and the political activity of the industry's representatives change as well. In this article, therefore, the term "industry preferences" refers to the aggregate preferences of the firms in an industry for free trade or protection, as interpreted and articulated by the industry's primary advocates in the political arena. These preferences, in turn, shape the strategies that the industry will use in response to the increasing import competition that follows a reduction in trade barriers.

Figure 1 shows the decision-making process of an industry in the wake of a reduction in the level of protection. The figure illustrates a simplified version of the options available to industries and the outcomes that result from choosing each alternative. The domestic industry must choose between two possible modes of action: adjust- 
ment and voice. The first path-adjustment—involves a change in the level and type of resources devoted to production. Producers adjust to changing market conditions by downsizing and revitalizing their production processes, specializing in specific sectors of the market in which they expect to be most competitive, or exiting from the industry altogether. The alternative channel of action is voice, "the act of complaining or of organizing to complain or to protest, with the intent of achieving directly a recuperation of the quality that has been impaired." 5

Two "voice" alternatives - administrative and legislative —are available to an industry. If an industry takes the administrative route, the International Trade Commission (ITC) must decide whether to grant protection. If the ITC chooses to grant protection, it must decide how much is required and what form it should take. Finally, the president has to decide whether to grant protection. If the president chooses to grant protection, he must decide whether to accept the ITC's recommendation or set his own policy. If the president declines to grant protection, Congress can overrule the decision with a two-thirds majority vote.

When an industry decides to take the legislative route, Congress must decide whether to pass legislation to grant trade protection to it. If Congress chooses to pass a bill, it must decide how much protection is needed and the form it should take. The president can then sign or veto the bill. If the president vetoes the bill, Congress can overrule the veto with a two-thirds majority vote.

If the industry chooses to forgo entering the political arena and simply adjusts to the new market conditions, the only mediating factors will be market characteristics and conditions, which together determine the ease with which the industry will be able to adjust to the more competitive environment.

An industry faced with increasing import competition in the wake of a trade barrier reduction will choose between adjustment and voice, and between the administrative and legislative routes of voice, by comparing the utility each alternative is expected to produce. Industries "base their lobbying on rational present-value calculations of their self-interest." ${ }^{6}$ They look to the impact a mode of action is expected to have on the present discounted value of their income streams. Although industries do not know the exact preferences of the other actors, they can predict the likelihood that the other actors will choose one option over another. Similarly, industries estimate the expected utility of each possible outcome. Based on these predictions, they calculate the expected utility of voice and adjustment and choose the path that promises the highest total expected utility.

The factors that determine which response an industry will choose when faced with increasing import competition after a trade barrier reduction fall into two broad categories: (1) the potential benefit of voice and (2) the perceived chance of success. The potential benefit of voice is the total additional benefit an industry expects to receive by obtaining protection rather than simply adjusting to the more competitive

5. Hirschman 1970, 76. The term "voice" was first coined by Hirschman, who used it to describe one of three channels of action available to economic organizations in decline.

6. Magee 1980, 138-53. 
market less the costs of exercising voice (for example, the costs of lobbying). The perceived chance of success is the probability that an industry will succeed in obtaining the protection it seeks.

The industry's choice of strategy is not necessarily exclusive. An industry may petition the ITC or attempt to push a bill through Congress while at the same time adjusting to changing market conditions. Investment in adjustment, however, necessarily weakens an industry's chance of obtaining administrative or legislative protection because it undermines its claim that it is suffering from severe economic distress and because it often involves a reduction in the size of the industry. Although an industry can (and typically does) pursue both voice and adjustment simultaneously, I treat them as discrete alternative strategies to highlight the process by which an industry chooses one or the other as its primary strategy. The case studies, however, explore the possibility of mixed strategies. In addition, despite important distinctions between legislative and administrative voice, for the most part I treat voice as a single option. This simplifies the model without significantly reducing its explanatory capacity.

\section{Variables Influencing Industry Strategy}

The potential benefit of voice and the perceived chance of success are the two key determinants of the trade policy strategies of producer groups. An explanation of these two categories and of the factors influencing them is therefore necessary for a full understanding of the strategic decisions of producer groups. ${ }^{7}$

\section{Potential Benefit of Voice}

The potential benefit of voice is the total benefit an industry receives from securing protection. As such, it is a function of the cost of adjustment, because an industry that secures protection will avoid having to adjust fully to a more competitive market. The level and means of protection will determine how much the industry will have to adjust. The potential benefits of administrative and legislative voice differ only in magnitude. They both depend on the cost of adjustment and are therefore affected by the same factors. Because administrative protection tends to be more porous, the potential benefit to the industry of the administrative route is generally not as great as the potential benefit of the legislative route. On the other hand, the cost to the industry of pursuing the administrative route tends to be significantly lower than the cost of pursuing the legislative route, particularly if the industry can credibly claim that it is suffering from severe economic distress.

7. The variables that determine the potential benefit of voice and perceived chance of success are largely drawn from numerous theoretical works that address the demand for and supply of protection, especially Conybeare 1991, 57-81; Hansen 1990, 21-46; Rogowski 1987b, 203-23; Rogowski 1987a, 1121-37; Lavergne 1983; Anderson and Baldwin 1981; Ray 1981, 105-21; Baldwin, Mutti, and Richardson 1980, 405-23; and Baldwin 1979. 
Several factors determine the potential benefit to an industry of obtaining protection. The most important are capital intensity, trade dependence, and factor specificity. Given relative factor endowments in the United States, capital intensity and trade dependence are inversely related to the potential benefit of obtaining protection. Factor specificity, on the other hand, is positively related to the potential benefit of obtaining protection.

Capital intensity. The impact of capital intensity on industry preferences is the subject of ongoing debate. The Stolper-Samuelson theorem suggests that trade protection tends to favor a nation's scarce factors of production and industries that use those factors relatively intensively. On the other hand, trade protection can harm abundant factors of production and industries that use those factors relatively intensively by increasing the probability that other countries will engage in retaliatory protection, thereby impeding the industries' access to foreign markets. This suggests that labor-intensive industries in the United States would tend to be more protectionist than capital-intensive industries (since the United States is considered to be relatively abundant in capital and relatively scarce in labor), at least in the long run. ${ }^{8}$

Capital intensity is also a primary determinant of the level of entry barriers. An industry with low capital intensity usually has low barriers to entry, since the cost of starting a business in that industry is relatively low. For such industries, nontariff barriers are highly porous and supply highly elastic, because countries not covered by the trade restriction can begin production relatively quickly and easily. ${ }^{9}$ In contrast, industries with relatively high capital intensity and thus high entry barriers will find trade barriers more effective at stemming the tide of foreign imports.

Trade dependence. Industries that depend on trade for a significant portion of their income are unlikely to favor trade protection and may even actively oppose it. ${ }^{10}$ Industries that export a large percentage of their total production are more likely to be hurt by the threat of foreign retaliation against their exports than they are to benefit from greater protection of their import-competing products. Similarly, if an industry depends on income generated by importing goods into the U.S. market or on the import of intermediate goods for its production process, a rise in import duties or imposition of quotas will lower profits. Indeed, Helen Milner has convincingly argued that the proliferation and deepening of international economies that took place after World War II helped create a pro-trade business community that served to counter protectionist sentiment in the 1970s and 1980s. ${ }^{11}$

Factor specificity. Factor specificity measures the extent to which a factor of production has an available alternate use in which it can earn a similar rate of return. It is positively correlated with the potential benefit of voice (the return to lobbying

8. Rogowski 1989, 93-96.

9. Bhagwati 1988, 54-59.

10. See Anderson and Baldwin 1981,24-25; Rogowski 1989; and Helleiner 1991.

11. Milner 1988. 
for specific government policies). ${ }^{12}$ If a factor can be transferred without cost from one activity to another, the owner of that factor has no reason to lobby for sectorspecific protection. If an asset is highly specific to a sector, however, its owner is dependent on the sector's fortunes. The harder it is for an industry to move its assets to another use, the harder it is for the industry to adjust and the more an industry has to lose from a reduction in the level of protection.

\section{Perceived Chance of Success}

The perceived chance of success is the expected probability that an industry will be successful in its efforts to obtain protection. The model refers to the perceived chance of success because the industry's decision about how to proceed is based on incomplete information. It does not know the payoff structures of the other actors and cannot know for certain which outcome will result from its choice. The industry can only predict the probability that the other actors will choose to act for or against it, and it bases its choice of strategy on such predictions.

Although it is impossible to model exactly the process by which an industry determines its chance of success in the political arena, it is possible to specify some key factors that it is likely to consider. These factors are basically those that public choice theorists associate with "the supply of protection." They include the receptiveness of the administration to protectionist arguments, the receptiveness of Congress to protectionist arguments, the size of the industry, the level of industry distress, and, perhaps most important, the past success of similar efforts. ${ }^{13}$ Thus, although the theory of dynamic preferences and strategies is a theory only of demand for protection, it must take account of the apparent likelihood of supply (from the point of view of the industry) to the extent that it affects an industry's choice between voice and adjustment.

Receptiveness of the administration to protectionist arguments. Administration receptiveness affects the industry's prediction of the probability of a favorable decision by the president or the ITC. The term "receptiveness" describes the administration's receptiveness to protectionist arguments as revealed in past actions and public statements. The administration's receptiveness to the protectionist arguments of a particular industry is also influenced by the pressure the administration is receiving from other societal groups for free trade or protection. Since the ITC is a part of the executive branch and its top officials are appointed by the White House, the willingness of the ITC to administer protection is a function (though not necessarily a perfect reflection) of administration receptiveness to protectionist arguments.

Receptiveness of Congress to protectionist arguments. When considering the probability that Congress will pass a favorable bill, the industry takes into account the receptiveness of the members of the House of Representatives and the Senate to

12. On the influence of asset specificity on incentives to lobby, see Frieden 1991, 19-22.

13. For more on the factors influencing the supply of protection, see, for example, Conybeare 1991; Frey 1984, 199-224; and Anderson and Baldwin 1981, 20-36. 
protectionist arguments. The more favorable Congress appears to be toward the industry considering political action, or toward protection in general, the higher the predicted probability that Congress will pass a bill in its favor. Here, too, I use the term "receptiveness" to describe Congress's receptiveness to protectionist arguments as revealed in past actions and public statements and as influenced by the demands of other groups for free trade or protection. ${ }^{14}$

Size. The size of an industry, as measured by level of output and level of employment, increases its political clout and thus its predicted chance of success. ${ }^{15}$ For obvious reasons, politicians tend to be more responsive to industries that employ a large number of people and possess large financial resources. A related variable, industry concentration, may also be an important determinant of an industry's ability to obtain protection, although its relationship to levels of protection is the focus of debate. ${ }^{16}$ Because of this uncertainty, the model does not incorporate industry concentration. ${ }^{17}$ However, I examine the effect of industry concentration on the political activities of the industry in the case studies.

Industry distress. Not surprisingly, the level of industry distress is one of the stronger indicators of the likelihood an industry will obtain protection. Indeed, according to a study by Wendy Hansen, this is the only consistent predictive factor of favorable ITC decisions. ${ }^{18}$ An industry's likelihood of obtaining protection from imports is strengthened if it can point to clear evidence of distress, such as slow or negative growth, high industry-related job loss and unemployment, low capacity utilization, and high import penetration. ${ }^{19}$

Past success. Probably the strongest influence on an industry's perceived chance of success is the recent decisions of the president, ITC, and Congress. If an industry has made successful petitions in the recent past or if similar petitions by other industries have been successful, an industry's estimation of its probability of success will be relatively high..$^{20}$

\section{Industry Ideal Types}

The potential benefit of voice and perceived chance of success are the primary determinants of an industry's actions in the face of higher import competition after a trade

14. Lutz 1991, 301-28.

15. Cassing, McKeown, and Ochs 1986, 853.

16. Mancur Olson has argued that more concentrated industries are more likely to obtain protection since the costs of organization are lower. Olson 1971. See also Finger, Hall, and Nelson 1982, 452-66; Anderson and Baldwin 1981,23; Ray 1981, 108; and Pincus 1975, 757-78.

17. See, for example, Aggarwal, Keohane, and Yoffie 1987, 345-66; Cassing and Hillman 1986, 516-23; and Finger, Hall, and Nelson 1982.

18. Hansen 1990, 30. See also Staiger and Wolak 1994.

19. See Hansen 1990, 30; and Lavergne 1983, 87-88.

20. Wendy Tacaks, for example, argues that "if many groups seeking protection have been successful in the recent past, other groups would be encouraged via a 'demonstration effect' to present their case as well." Tacaks 1981, 698. See also Staiger and Wolak 1994, 61-63, 78-81, 91-93. 
TABLE 1. The four industry types

\section{Perceived chance of success}

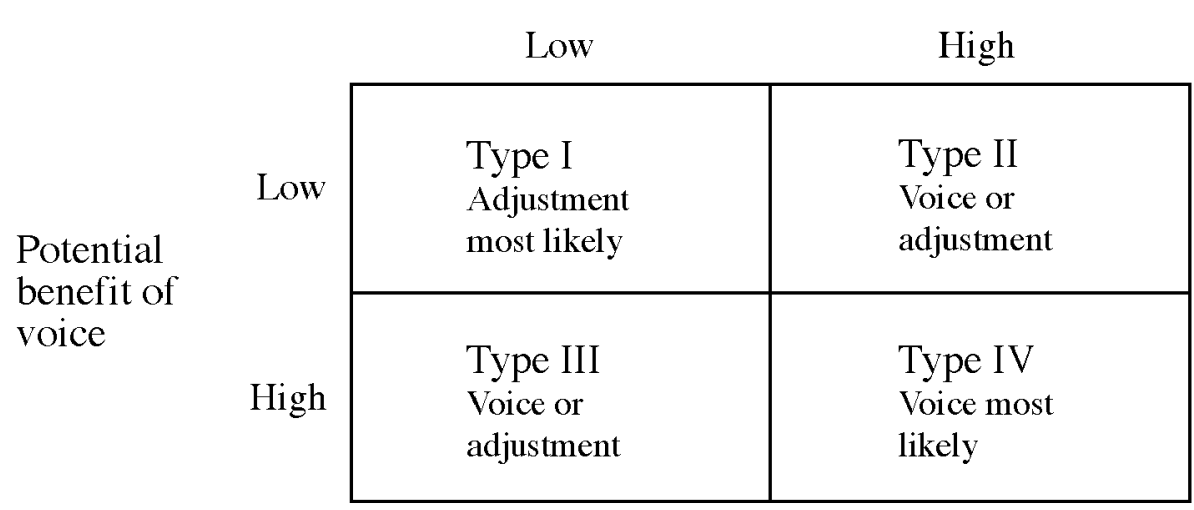

TABLE 2. Characteristics of the four industry types

\begin{tabular}{lllll}
\hline & Type I & Type II & Type III & Type IV \\
\hline Potential benefit & & & & \\
$\quad$ Capital intensity & $\mathrm{H}^{\mathrm{a}}$ & $\mathrm{H}$ & $\mathrm{L}^{\mathrm{b}}$ & $\mathrm{L}$ \\
Trade dependence & $\mathrm{H}$ & $\mathrm{H}$ & $\mathrm{L}$ & $\mathrm{L}$ \\
$\quad$ Factor specificity & $\mathrm{L}$ & $\mathrm{L}$ & $\mathrm{H}$ & $\mathrm{H}$ \\
Chance of success & $\mathrm{L}$ & $\mathrm{H}$ & $\mathrm{L}$ & $\mathrm{H}$ \\
Receptiveness of administration & $\mathrm{L}$ & $\mathrm{H}$ & $\mathrm{L}$ & $\mathrm{H}$ \\
Receptiveness of Congress & $\mathrm{L}$ & $\mathrm{H}$ & $\mathrm{L}$ & $\mathrm{H}$ \\
Size of industry & $\mathrm{L}$ & $\mathrm{H}$ & $\mathrm{L}$ & $\mathrm{H}$ \\
Industry distress & $\mathrm{L}$ & $\mathrm{H}$ & $\mathrm{L}$ & $\mathrm{H}$ \\
Past success & & & & \\
\hline
\end{tabular}

${ }^{\mathrm{a}} \mathrm{H}=$ relatively high.

${ }^{\mathrm{b}} \mathrm{L}=$ relatively low.

barrier reduction. They define four ideal-typical categories of industries with different preferences and strategies. These four ideal types are outlined in Tables 1 and 2.

Type I industries are those for which the costs of pursuing protection outweigh the benefits. They will choose to adjust rather than pursue protection in either the administrative or legislative arenas. For these industries, both the benefit of obtaining protection and the perceived chance of success are low. Type II and type III industries may choose voice or adjustment or some combination thereof. Finally, type IV industries are those for which the costs of pursuing protection are outweighed by the benefits. These industries are the most protectionist and will consistently choose voice over adjustment. 


\section{A Theory of Dynamic Preferences and Strategies}

Having examined the factors that influence the choice of strategies by industries, I now develop a theory of dynamic producer group preferences and strategies to account for the impact of a reduction of trade barriers on the preferences and strategies of industries. Adding an intertemporal perspective shows how trade liberalization can increase the global competitiveness of firms, lower the potential costs of future trade liberalization, and thereby make producer groups less likely to demand trade protection.

Industries that experience a reduction in the level of protection-whether resulting from a trade agreement, unilateral trade liberalization, or decreasing effectiveness of existing protection-will either exercise voice or adjust to the more competitive environment. Industries that exercise voice may win full, partial, or no protection from foreign competition. The amount that they will then be forced to adjust will vary with the level and type of protection awarded. Industries that choose to adjust will become more competitive by focusing production in areas where they are relatively more efficient, reducing capacity, undertaking technological improvements, changing management strategies, and reducing costs. This process of adjustment has an important, and often overlooked, effect on the factors that influence both potential benefit of voice and perceived chance of success. By forcing industries to adjust to a more competitive market, a reduction in protection levels changes their preferences and strategies and thus their level of future political activity. Effects in one period become causes in the next (see Figure 2).

When an industry adjusts to an increase in import competition after a trade barrier reduction, the adjustment usually affects the factors that determine the potential benefit of obtaining protection. Capital intensity and trade dependence-which are inversely related to the potential benefit of obtaining protection-often increase. Factor specificity - which is positively related to the potential benefit of obtaining protection-generally remains unchanged. As a result of these changes, the potential benefit of voice falls.

An industry in the United States can adjust to the more competitive market conditions that follow a trade barrier reduction by increasing its capital intensity. This usually involves investing in machinery that can complete tasks more quickly and efficiently than human labor, while reducing the number of employees. (A strategy of simply "downsizing" by laying off workers may also result in a limited increase in capital intensity.) Since capital is relatively abundant in the United States, firms that increase the relative amount of capital involved in the production process are likely to become more competitive at home and abroad. Thus, when firms choose to adjust by increasing their capital intensity, the potential benefit of obtaining protection falls.

Firms can also adjust to more competitive market conditions by becoming more active in international trade. First, when import barriers fall, firms that earn low returns on their domestic manufacturing activities may import finished goods for sale in the domestic market to improve their profits. Second, firms may opt to "farm out" the more labor-intensive activities involved in their production processes to low- 


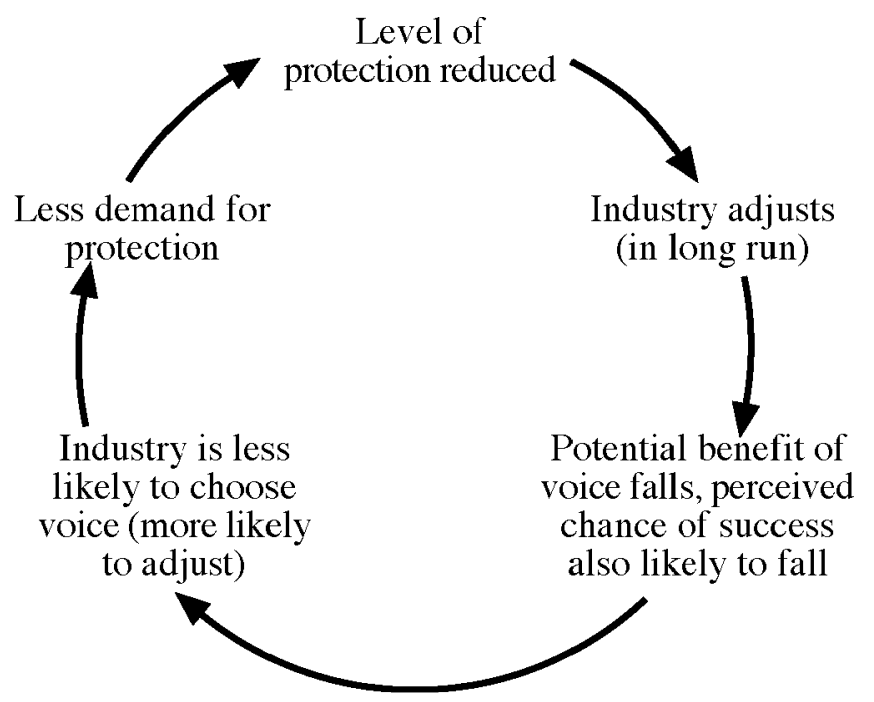

FIGURE 2. The positive feedback effect

wage countries (such as Mexico and the nations of the Caribbean) or import intermediate products to reduce their production costs. Third, firms may begin to explore export opportunities, particularly if the trade barrier reduction is reciprocal. As a result of these changes, trade dependence-which is inversely related to the potential benefit of obtaining protection-generally increases when an industry adjusts to a more competitive market in the wake of a trade barrier reduction.

Because economic adjustment can be expensive and difficult to implement, it often occurs in jumps. For instance, a single computer-aided design (CAD) machinewhich can cost well over a million dollars - can cut a firm's labor costs to a fraction of its previous levels and multiply a firm's efficiency, speed, and accuracy severalfold. Similarly, shifting labor-intensive processes abroad, importing intermediate and finished goods, and exporting products all carry high start-up costs (primarily the costs of information gathering and establishing contacts with buyers and sellers) but can yield large benefits. Moreover, once a firm begins these activities, additional incremental adjustments are easier and less expensive to make. Thus, firms that survive in the wake of a trade barrier reduction may not only continue to operate but may actually become formidable competitors in the international market.

The cumulative effect of these changes is to reduce the severity of future adjustment and thus the potential costs of future trade liberalization. When an industry that has been forced to adjust is subsequently faced with the prospect of another reduction in the level of protection, it again has two options: voice or adjustment. Yet, because of the previous reduction in protection, adjustment is relatively less costly and thus more attractive than it would otherwise have been. Moreover, those less-efficient firms in the industry that were unable to adjust and went out of business are no longer part of the population of firms in the industry. The industry as a whole is thus more 
likely to favor-or at least less likely to oppose through use of voice-a further reduction of trade barriers. Reductions in the level of protection thereby decrease the number of active and vocal opponents of trade liberalization.

The reduction in the potential benefit of voice in the wake of a trade barrier reduction is contingent on industry adjustment to more competitive market conditions. The predicted change in trade policy preferences and strategies will not come about until the industry adjusts. How long that takes will depend primarily on the level of barriers to exit in the industry, which is highly correlated with asset specificity. ${ }^{21}$ Thus, industries with high asset specificity may remain stridently protectionist for a longer period of time after a reduction in the level of protection than industries with low asset specificity and hence low barriers to exit.

The factors that determine the perceived chance of success are also affected by the adjustment process that follows a reduction in the level of protection. Most notably, the size of the industry and the past success rate are both likely to fall. In addition, the industry is likely to perceive the administration and Congress as less receptive to protectionist arguments. The level of industry distress, however, is likely to increase, at least for a short time.

The size of an industry, which positively influences the perceived chance of success, is expected to fall in the wake of a trade barrier reduction. A reduction in employment generally accompanies an effort to increase efficiency and meet the challenge of growing foreign competition. The number of firms in the industry also tends to fall when foreign competition increases, since the least efficient firms are forced out of business.

A final factor that is also positively related to the perceived chance of success, the past success rate, is expected to fall by a marginal amount after a reduction in trade barriers. Because the industry will have lost its most recent effort to prevent a reduction in the level of protection, it is likely to feel less confident of its future chance of success in the political arena.

In summary, only one factor that is positively related to the perceived chance of success, the level of industry distress, should increase as a consequence of a reduction in the level of protection. In the short term, rising industry distress may make an industry that is subject to a reduction in trade barriers more willing to enter the political arena and more likely to gain a sympathetic hearing from public officials. Over the long term, however, the effects of this shift are outweighed by the other changes that take place in the industry as a result of heightened import competition.

The process just outlined has implications for the evolution of the industry types introduced earlier. As Table 3 illustrates, the four industry types are affected differently by an increase in import competition following a reduction in trade protection. Eventually, however, the adjustment process pushes them all in the same directiontoward the characteristics of a type I industry.

After a trade barrier reduction, type I industries choose to adjust to more competitive market conditions and are likely to continue to do so. Type II and type III indus- 
TABLE 3. Changes in industry types after a reduction in trade barriers

Perceived chance of success

Low

High

Potential

benefit of

voice

Low \begin{tabular}{|l|ll|}
\hline $\begin{array}{l}\text { Type I } \\
\text { Adjustment } \\
\text { most likely }\end{array}$ & & $\begin{array}{l}\text { Type II } \\
\text { Voice or } \\
\text { adjustment }\end{array}$ \\
\cline { 2 - 4 } & $\begin{array}{l}\text { Type III } \\
\text { Voice or } \\
\text { adjustment }\end{array}$ & $\begin{array}{l}\text { Type IV } \\
\text { Voice most } \\
\text { likely }\end{array}$ \\
\hline
\end{tabular}

tries that are not successful in obtaining protection are forced to adjust to the more competitive market conditions. As they adjust, they become more like type I industries. How much they are forced to adjust depends on how much trade protection remains. Type IV industries undergo a process similar to that experienced by type II and type III industries. The amount they are forced to adjust is determined by the level of protection granted by legislative and administrative officials. If the industry does not receive protection or receives only partial protection, it will become more like a type I, II, or III industry, depending on the extent and type of adjustment it is forced to undergo.

As a result of the adjustment process, the industry changes the way it employs scarce resources. Capital and labor that once went into the less efficient production processes are transferred to more efficient production processes within the industry or reallocated to more efficient industries. Owners of capital in a noncompetitive industry "will expend resources to influence government policy toward their industry up to the point where it would make more sense for them to find another use for their resources." 22 Since the process of adjustment increases the likelihood that owners of capital will shift their resources to other activities, the effect is to reduce the amount of scarce resources industries devote to demanding trade protection.

This model does not predict that reductions in trade barriers will lead to the elimination of protectionist demands, but rather that the societal actors who vocally oppose free trade will be fewer in number. Not all actively protectionist industries will be less vociferous after a trade barrier reduction, only those forced to undergo substantial adjustments. Moreover, the model does not predict that protectionist activity will fall immediately after a reduction in trade barriers. Indeed, in the short run, an industry that is subject to a reduction in trade barriers will probably become more willing to enter the political arena because it will be suffering greater distress. But, as an industry affected by the reduction in trade barriers adjusts-that is, as its size 
shrinks, its capital intensity rises, and its trade dependence increases-it will become less willing to undertake the costs associated with pursuing protection and more willing to adjust. Thus, the common prediction that an increase in import competition will lead to greater demand for protection may be accurate in the short run, but it becomes less so over time as industries adjust. This is precisely why an intertemporal approach to industry demand for protection is essential.

\section{The Dynamics of Demand for Protection: The Case Studies}

To test the accuracy of the model, I examine three industries that appear to present the hardest cases for the argument. Because a well-established and widely accepted hypothesis of the trade policy literature is that high and rising levels of import penetration lead industries to pursue protection, I trace the evolution of three industries that faced strong foreign competition after an initial reduction in the level of protection: footwear, textiles, and apparel. According to traditional models, these industries should be among the most protectionist, with a strong and rising interest in import restraints. In contrast, my model predicts that these industries should become less protectionist as they adjust to more competitive markets. As will become clear, this is indeed what happened in all three industries during the last quarter-century, suggesting that the model is accurate and that other industries faced with similar conditions will also reduce their demands for protection.

\section{The Footwear Industry}

From World War II to the 1970s, the U.S. footwear industry exemplified the protectionist type IV industries. Its primary political advocate, the Footwear Industries of America (FIA) - then called the American Footwear Industries Association (AFIA) did little else during this period but lobby for import relief. ${ }^{23}$ The members of the AFIA, which included all major U.S. shoe manufacturers, unanimously favored pursuing trade protection, a unity directly related to the characteristics of the footwear industry. ${ }^{24}$ First, the industry was relatively large and unconcentrated, composed primarily of small privately owned firms located in remote communities. ${ }^{25}$ Although production was dispersed among many producers, the industry was geographically concentrated. ${ }^{26}$ Second, footwear production during this period was highly labor intensive, with labor costs accounting for approximately one-third of the price of a pair of shoes. ${ }^{27}$ The semiskilled laborers employed by the industry tended to have few attractive employment alternatives, which made adjustment to changing market conditions especially difficult for them. ${ }^{28}$ Capital investment in the footwear industry

23. Author's interview with Fawn Evenson, president of Footwear Industries of America, Washington, D.C., August 1993; see also Milner 1988, 110; Yoffie 1983a, 323-24; and Yoffie 1983b, 174.

24. Author's interview with Fawn Evenson.

25. See USITC 1976a; OECD 1976; and Szenberg, Lombardi, and Lee 1977, 7-15.

26. See Yoffie 1983b, 174; and Yoffie 1983a, 323-24.

27. Yoffie 1983b, 173.

28. Workers in the footwear industry tended to be younger than twenty and older than sixty, and two-thirds of the workforce were female. Unemployment in the industry was persistently high for several 
was low. Most footwear firms were too small to afford significant investments in new machinery. ${ }^{29}$ Even for those firms with the necessary funds, little technology was available to reduce the labor intensiveness of the production process. ${ }^{30}$ The low capital requirements for entry into the market, low skill level of the workplace, and low capital intensity made the industry highly vulnerable to competition from low-wage developing countries. ${ }^{31}$ Finally, the footwear industry had a very low level of trade dependence. ${ }^{32}$ Exports never grew beyond a paltry 0.05 percent of domestic consumption. ${ }^{33}$ The ratio of foreign assets to total assets remained less than 5 percent throughout the 1960s and 1970s. ${ }^{34}$ These characteristics suggest that the footwear industry had a high perceived chance of success and a high potential benefit of voice-a classic type IV industry.

In the years following World War II, the U.S. shoe industry dominated the American market, capturing 99.6 percent of the market in 1947, 98.8 percent in 1950, and 98.7 percent in $1955 .{ }^{35}$ During the 1960s, however, Europe and Japan emerged fully recovered from the destruction of World War II, and the Pacific Rim countries embarked on the path of industrialization. Many traditional U.S. manufacturing industries began to feel the pressure of increasing foreign competition. One of the more profoundly affected was the footwear industry. ${ }^{36}$

The footwear industry began to face high and rising import competition during the 1960s, especially after the 1968 Kennedy Trade Round, which lowered tariffs on shoes by close to 50 percent. The resulting surge in imports impelled the industry, which then had a high potential benefit of voice and high perceived chance of success, to seek protection. It met with only limited success. An escape clause case initiated in 1968 by presidential candidate Richard Nixon ended in a hung jury, and after he was elected, President Nixon declined to impose trade barriers, choosing instead to authorize adjustment assistance for eleven shoe plants. ${ }^{37}$ The industry's near-perfect record of past success was marred by these failures, but its efforts had not been completely unsuccessful. The Tariff Commission's tied vote and the president's decision to grant adjustment assistance indicated that they were open to the industry's pleas.

decades, sometimes as much as twice the national average. Moreover, footwear firms were often located in smaller communities where they employed a large percentage of the local population. As a result, workers in the industry had difficulty finding new jobs. See Washington Post, 29 August 1985, C1; and Pearson 1983,6 .

29. Burton and Yoffie 1986, 5 .

30. Ibid.

31. See USITC 1976a, A71, A75; OECD 1976; and Yoffie 1983a, 324-27.

32. Author's interview with Fawn Evenson; see also U.S. Department of Commerce 1977; and U.S. Department of Commerce 1979a, 1981, and 1982a.

33. See U.S. Department of Commerce 1979a and 1982a.

34. See U.S. Department of Commerce 1977 and 1981.

35. Footwear News, 6 October 1985, 2 .

36. This case study focuses primarily on the nonrubber footwear industry, which is classified under U.S. Department of Commerce Standard Industrial Classification code 314.

37. Author's interview with Fawn Evenson; see also Business Week, 4 July 1977, 17; and Hufbauer, Berliner, and Elliott 1986, 206-17. 
During the early 1970 s, the footwear industry repeatedly sought protection from imports and repeatedly met with failure. The most significant failure was the defeat of the Trade Bill of 1971, which enjoyed strong support by the industry and would have imposed quantitative import restrictions on footwear. ${ }^{38}$ Between 1973 and 1979, the industry brought seven countervailing duty (CVD) cases and won duties against Brazil, Spain, and Argentina. But the CVDs failed to stem the rising tide of foreign competition. Import penetration - the ratio of imports to total domestic consumptionsurged 111 percent between 1968 and 1976,,$^{39}$ the highest rate of increase in import penetration of any U.S. manufacturer. ${ }^{40}$ Footwear producers won some trade assistance in the 1974 Trade Act, but the legislation did not bind the administration to act. ${ }^{41}$ In 1975, the AFIA initiated an escape clause case with the ITC. Although the ITC found that the industry had been injured by imports and recommended relief, President Gerald Ford refused to implement the recommendations. ${ }^{42}$ A month after the decision, imports of nonrubber footwear reached a record high of 49 percent of the domestic market. ${ }^{43}$

In the fall of 1976, under pressure from the industry and Congress, the ITC reopened the nonrubber footwear escape clause case. The ITC recommended that a combination of tariffs and quotas be imposed on a country-by-country basis for five years. ${ }^{44}$ In April 1977, however, President Jimmy Carter rejected the recommendations in favor of two Orderly Marketing Agreements (OMAs) with Taiwan and Korea, an expanded program of adjustment assistance, and the formation of a footwear industry advisory committee for the Tokyo Round of the General Agreement on Tariffs and Trade (GATT) negotiations ${ }^{45}$ Although the OMAs and increased adjustment assistance provided a limited degree of relief, ${ }^{46}$ imports from the rest of the world continued to surge, and domestic production of nonrubber footwear dropped steadily, from 430.9 million pairs in 1977 to 377.2 million pairs in $1981 .{ }^{47}$

In 1979, the industry - which, as Figures 3, 4, and 5 indicate, was suffering from extreme economic distress-won changes in U.S. trade laws that reduced the cost of pursuing import relief, succeeded in getting a footwear industry advisory committee included in the group of industry advisors for the Tokyo Round of the GATT negotiations (the committee kept GATT tariff cuts on footwear products minimal and recip-

38. See Milner 1988, 109; and Yoffie 1983a, 355.

39. American Footwear Industry Association 1983.

40. See U.S. Department of Commerce 1979b and 1982b.

41. See Milner 1988, 109; and Yoffie 1983a, 337.

42. USITC $1976 \mathrm{~b}$.

43. Footwear News, 6 October 1985, 2.

44. USITC 1977.

45. For more on the events of 1976, see Yoffie 1983a. For more on the 1977 decision and the circumstances surrounding it, see Washington Post, 23 July 1977, A4; Washington Post, 30 June 1977, D1; and Newsweek, 11 April 1977, 80.

46. There is some disagreement over how much relief the OMAs provided to the footwear industry. Compare Footwear News, 6 October 1985, 2 (arguing that OMAs provided much needed relief to the footwear industry), with Yoffie 1983a, 313-39 (arguing that the quantitative limits actually strengthened foreign importers vis-à-vis domestic producers).

47. Footwear News, 6 October 1985, 2. 


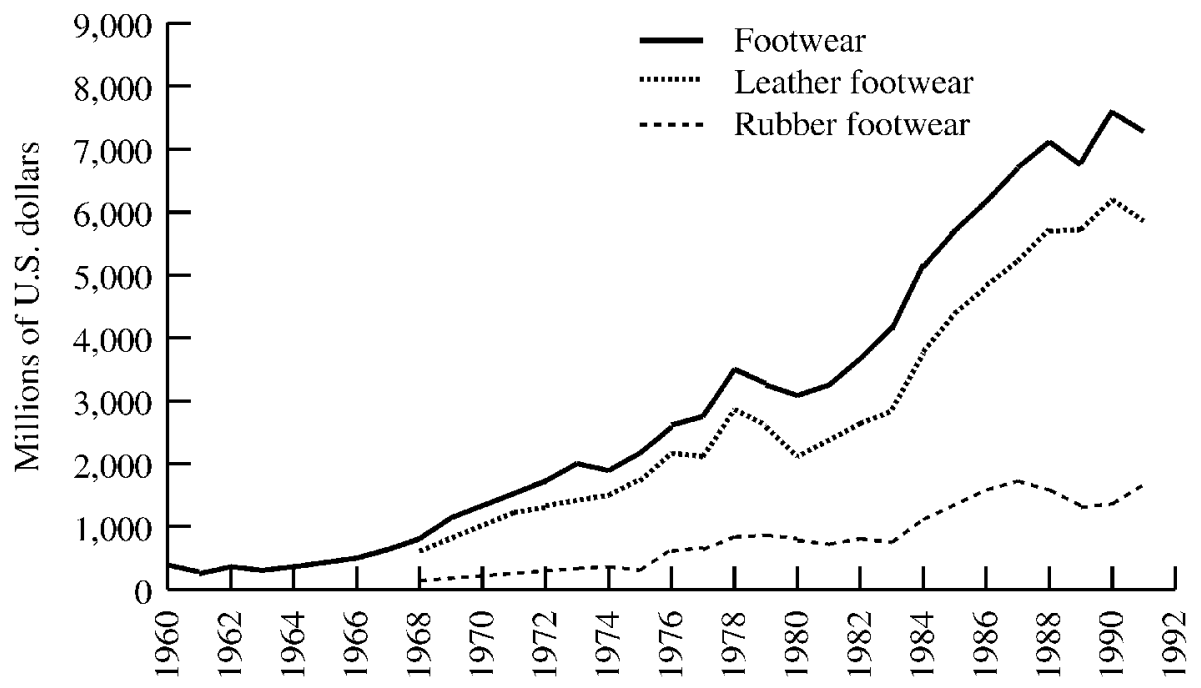

Source: UN Department of International Economic and Social Affairs Statistical Office, 1950-91.

FIG URE 3. Imports of footwear into the United States, 1960-91 (adjusted using an industry-based producer price index)

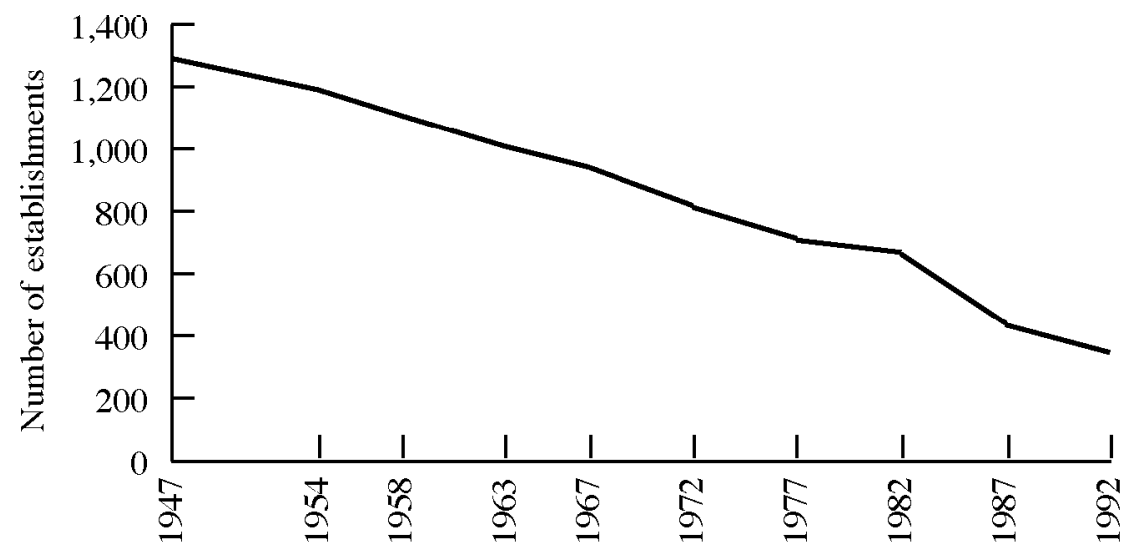

Sources: U.S. Bureau of the Census 1971, 1976b, 1990, 1996b.

Note: Data before and after 1972 are not completely comparable due to a minor change in the Standard Industrial Classification (SIC) codes.

FIG URE 4. Establishments in the footwear industry, 1947-92 


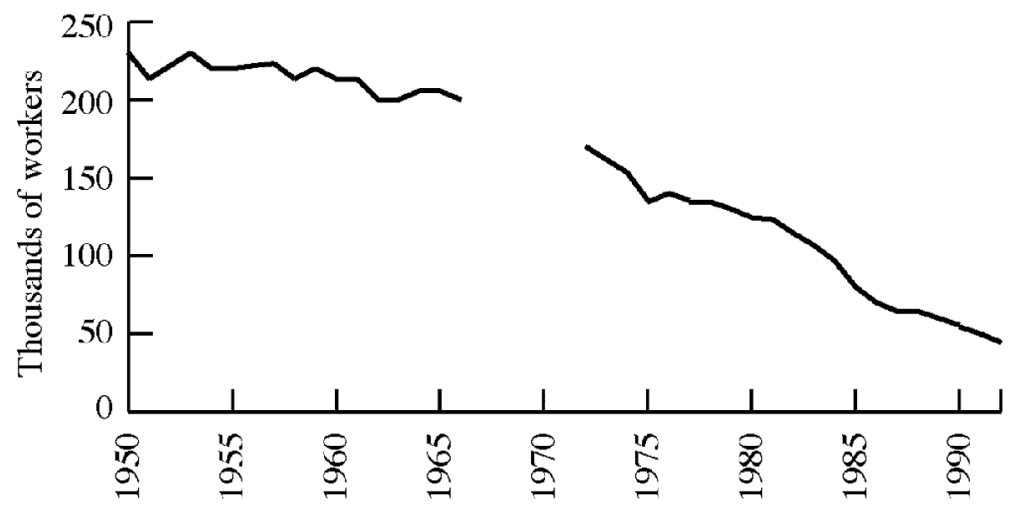

Sources: U.S. Bureau of the Census 1971, 1976b, 1990, 1996b.

Note: Data before and after 1972 are not completely comparable due to a minor change in SIC codes. Comparable data not available for 1968-71.

FIG URE 5. Employment in the U.S. footwear industry, 1950-92

rocal), and developed a formal footwear caucus in the House and Senate to press its views. ${ }^{48}$ These minor political successes again failed, however, to stem the increase in shoe imports. During the 1970s and 1980s, the size of the industry fell as smaller, less competitive firms either went out of business or were purchased by larger firms. As Figure 4 shows, between 1967 and 1987 the number of firms manufacturing shoes in the United States declined by more than 50 percent, from 951 to 446, and the number of plants dropped from 1,100 in 1970 to 594 in $1981 . .^{49}$ Employment in the industry also fell dramatically, from 216,340 in 1960 to 125,700 in 1980 to 57,800 in 1990 (Figure 5). As a result, output became even more concentrated in a few large firms (Figure 6). Many of the firms that survived the onslaught of foreign competition did so by moving plants to low-wage states, investing in advanced machinery, diversifying into the import and retail sectors, importing the components that required the most labor to produce, and farming out the most labor-intensive portions of the production processes to nearby low-wage countries in the Caribbean and Latin America. As Figure 7 demonstrates, new capital expenditures rose dramatically. Domestic firms sought to capitalize on their one inherent advantage-location-by focusing on in-stock sizes and quick delivery. As the footwear industry adjusted, its potential benefit of voice and perceived chance of success began to fall, shifting the industry from a type IV industry toward a type III industry.

As some firms began adjusting to the more competitive market more rapidly than others, a split began to develop within the industry. Larger firms that were in a better position to compete with foreign producers became less interested in obtaining im-

49. Hufbauer, Berliner, and Elliott 1986. 


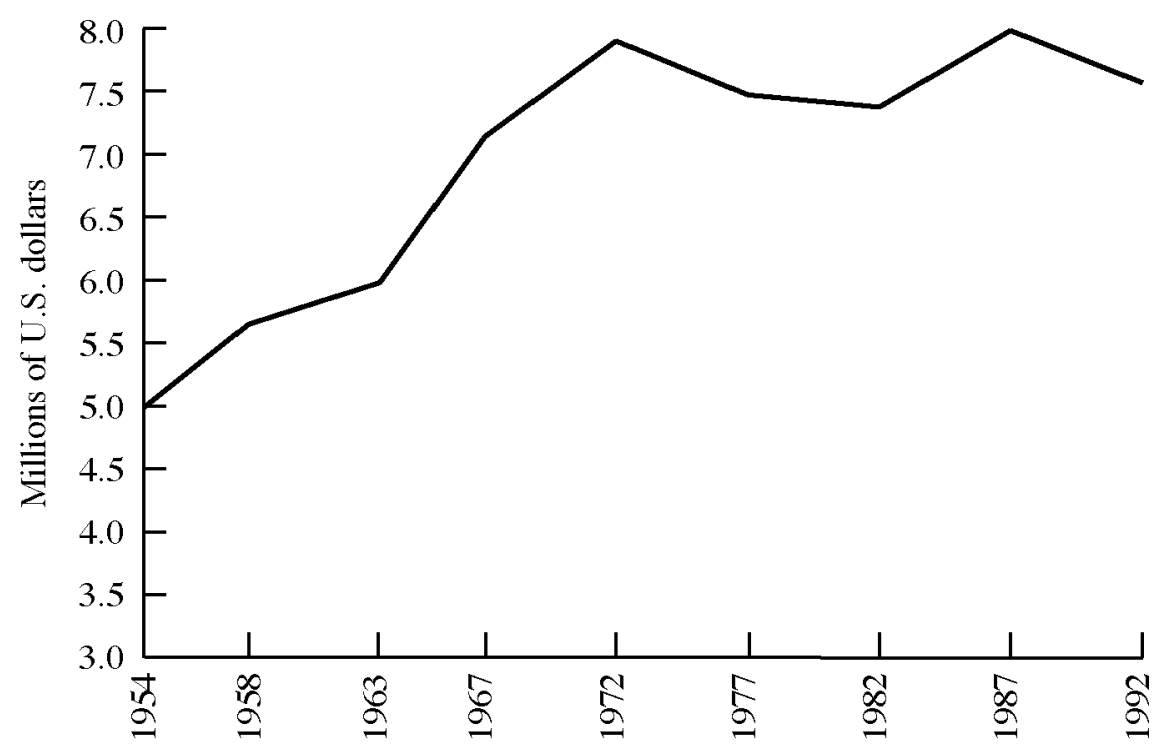

Sources: U.S. Bureau of the Census 1971, 1976b, 1990, 1996b.

Note: Data before and after 1972 are not completely comparable due to a minor change in SIC codes.

FIG URE 6. Concentration of the footwear industry, 1954-92 (measured as the value of output per establishment, adjusted using an industry-based producer price index)

port restrictions. These firms began withdrawing from the FIA and joining its opponent, the Volume Footwear Retailers Association (VFRA), which primarily represented shoe importers and retailers in the United States. ${ }^{50}$ In the mid-1980s, new technological innovations deepened the industry split. CAD and computer-aided manufacturing (CAM) significantly reduced the time and labor required for the design, manufacturing, and marketing of footwear. These innovations also led to a more consistent product and made quicker delivery possible. The new technologies were extremely expensive, however, and were therefore purchased only by larger firms with the necessary resources..$^{51}$

As larger shoe firms adjusted to the more competitive market and as smaller firms went out of business, the FIA's efforts to obtain protection were countered with increasing strength by the VFRA and its membership. In 1981, for instance, the 


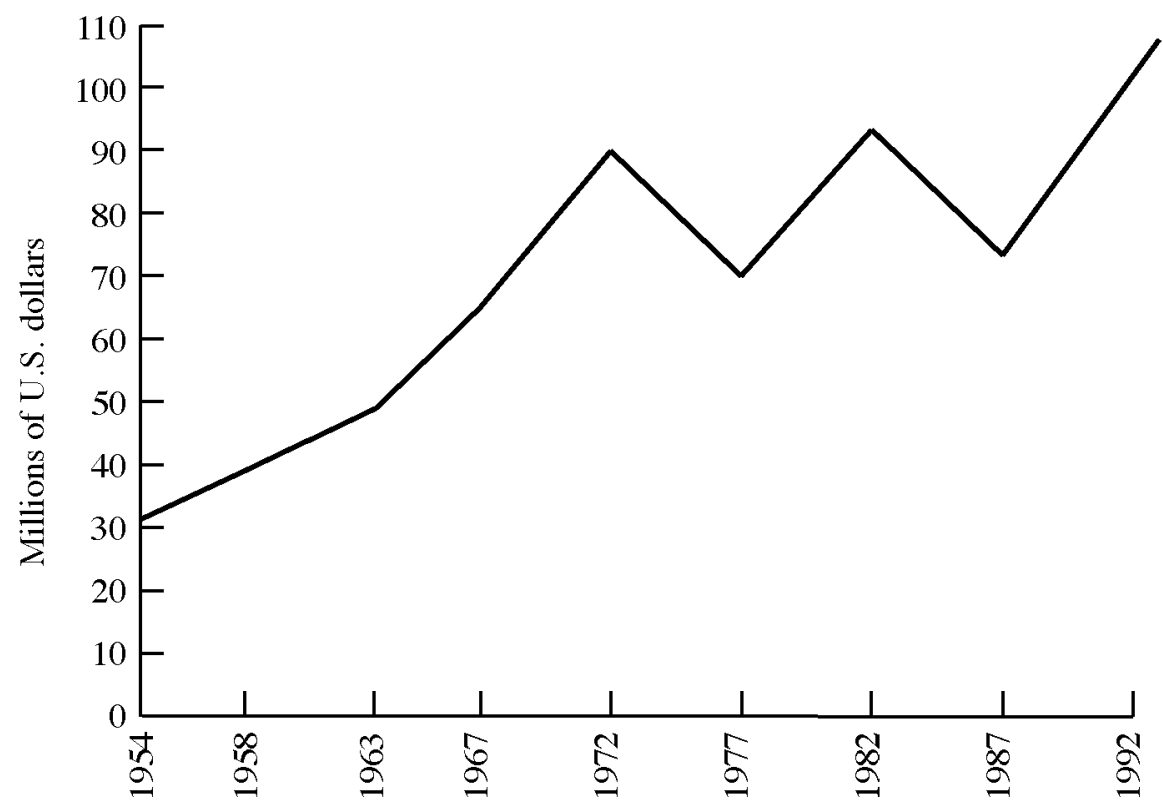

Sources: U.S. Bureau of the Census 1971, 1976b, 1990, $1996 \mathrm{~b}$.

Note: Data before and after 1972 are not completely comparable due to a minor change in SIC codes.

FIG URE 7. New annual capital expenditures per establishment in the footwear industry, 1954-92 (measured as the new capital expenditures per establishment (production plant), adjusted using an industry-based producer price index)

strongest opposition to the FIA's efforts to extend the OMAs with Taiwan and South Korea came from domestic manufacturers that had joined the VFRA when they began importing shoes from the Far East and Europe to supplement their product lines. ${ }^{52}$ The VFRA and its members won: President Reagan rejected the ITC's recommendation to renew the agreement with Taiwan and allowed both agreements to expire. ${ }^{53}$ As a result, import penetration of the U.S. footwear industry rose from 50.6 percent in 1981 to 58.7 percent in 1982, 64.3 percent in 1983, and over 75 percent in $1985.5^{54}$

Although the FIA succeeded in 1985 in obtaining an ITC recommendation of a five-year global quota of 55 percent on the U.S. nonrubber footwear market, President Reagan refused to impose the trade restraints. Instead, he authorized an adjustment and retraining program for workers in the industry. ${ }^{55}$ This decision convinced

52. See New York Times, 27 June 1981, 2-29; and Washington Post, 24 May 1981, F1.

53. USITC 1981.

54. See Yoffie 1983a, 2; and Christian Science Monitor, 2 July 1981, 24.

55. See Footwear News, 2 September 1985, 19; Footwear News, 12 August 1985; and Washington Post, 17 April 1985, F2. 
the footwear industry that it was unlikely to obtain any administrative protection from the Reagan administration. ${ }^{56}$ In 1985, the FIA lobbied Congress in an effort to get a footwear quota package incorporated into a pending trade bill. Although the bill provoked strong opposition from American retailers, importers, and consumer groups, it was overwhelmingly approved by both the Senate and House, not least because the members of Congress were certain the president would veto the bill. As expected, neither chamber managed to raise the two-thirds majority required to override the veto. ${ }^{57}$

This defeat led the FIA to conclude that it was unlikely to succeed in obtaining substantial import protection as long as President Reagan was in office. ${ }^{58}$ The industry's chance of success thus fell to the lowest it had ever been. The potential benefit of voice also continued to fall as firms were forced to adjust to the more competitive market or go out of business. The shift in the industry's attitude during this period is demonstrated perhaps most clearly by the FIA's decision in 1986 to focus less on pursuing import restrictions and more on promoting exports and helping firms adapt to new technologies. 59 The FIA began holding seminars aimed at helping its members incorporate new technologies into their production processes, sponsored an industry show intended to inform shoe producers about new cost-cutting module units, purchased four shoe-designing computer systems and invited its members to train on them to determine which system best suited their companies' needs, and sponsored a shoe summit to bring the industry together to discuss technological advances. ${ }^{60}$

But the FIA was not yet willing to give up entirely on obtaining protection. In 1987 and again in 1990, the FIA entered the political arena in joint efforts with the textile industry to obtain quantitative import restrictions. In both cases, a protectionist bill was approved by large margins in Congress but failed to gain enough votes to override the expected presidential veto. After experiencing its third major failure in the legislative arena in five years, the FIA finally decided, in the words of FIA president Fawn Evenson, to "stop spending one more penny or one more minute of our time on import restrictions." 61 In a remarkable shift in strategy, the FIA began to admit importers into its ranks and stopped pursuing trade barriers. ${ }^{62}$

As illustrated in Table 4, the reduction in trade barriers, failure of the industry to obtain additional protection, and economic adjustment within the industry had reduced the perceived chance of success and the potential benefit of voice. As a result, voice had become a less attractive option than economic adjustment. Indeed, when the 1991 Caribbean Basin Initiative threatened to lower tariffs on shoes coming from the Caribbean area, the FIA chose not to oppose the measure. Instead, it acted as an

56. Author's interview with Fawn Evenson.

57. See Washington Post, 24 November 1985, G1; Washington Post, 14 November 1985, E1; and Washington Post, 4 October 1985, B1.

58. Author's interview with Fawn Evenson.

59. Ibid.

60. See Footwear News, 3 July 1989, 21; Washington Post, 24 August 1987, F11; Footwear News, 21 April 1986, 1; and Footwear News, 14 April 1986, 1.

61. Author's interview with Fawn Evenson.

62. Footwear News, 19 November 1990. 
TABLE 4. Characteristics of the footwear industry prior to and following adjustment

Pre-adjustment

(1950-79)
Transition

(1980-89)
Post-adjustment (1989-94)

\section{Potential benefit \\ Capital intensity \\ Trade dependence \\ Factor specificity \\ Chance of success \\ Receptiveness of Congress \\ Size of industry \\ Industry distress \\ Past success \\ Approximate type

\footnotetext{
${ }^{\mathrm{a}} \mathrm{L}=$ relatively low.

${ }^{\mathrm{c}} \mathrm{H}=$ relatively high.
} \\ ${ }^{\mathrm{b}} \mathrm{M}=$ average.}

Receptiveness of administration

\begin{tabular}{lll}
$\mathrm{L}^{\mathrm{a}}$ & $\mathrm{M}^{\mathrm{b}}$ & $\mathrm{M}$ \\
$\mathrm{L}$ & $\mathrm{M}$ & $\mathrm{H}$ \\
$\mathrm{H}^{\mathrm{c}}$ & $\mathrm{M}$ & $\mathrm{M}$ \\
$\mathrm{H}$ & $\mathrm{M}$ & \\
$\mathrm{H}$ & $\mathrm{H}$ & $\mathrm{L}$ \\
$\mathrm{H}$ & $\mathrm{M}$ & $\mathrm{M}$ \\
$\mathrm{H}$ & $\mathrm{H}$ & $\mathrm{M}$ \\
$\mathrm{H}$ & $\mathrm{M}$ & $\mathrm{H}$ \\
$\mathrm{IV}$ & $\mathrm{II}$ & $\mathrm{L}$ \\
& & $\mathrm{I}$ \\
\hline
\end{tabular}

information broker between members interested in doing business in the Caribbean and U.S. trade officials. Similarly, the FIA opposed NAFTA “in principle," but spent little time and no money opposing the measure.

The history of the footwear industry supports the theory of dynamic preferences and strategies. During the two decades that followed World War II, the footwear industry was a classic type IV industry. When faced with increasing import competition in the wake of the Kennedy Round tariff reductions, the industry chose voice-as expected of a type IV industry - but met with only limited success in the political arena. The theory predicts that an import-affected industry not receiving full protection will be forced to adjust and that, as a result of this adjustment, the industry's potential benefit of voice and perceived chance of success will fall. This is exactly what happened to the footwear industry, although the process of adjustment took more than a decade. The process was slowed by the partial success of the industry in the political arena. The industry did eventually adjust, however, and its perceived chance of success and potential benefit of voice fell as predicted by the theory. What had been one of the most protectionist industries in America eventually stopped seeking import restrictions. Today, the U.S. footwear industry's characteristics and political activities are closest, though not yet identical, to those of a type I industry.

\section{The Textile and Apparel Industries}

The textile and apparel industries have long been among the most protectionist and most protected industries in postwar America. From the 1950s to the 1970s, the 
industries were among the largest manufacturing employers in the United Stateseven larger than the footwear industry - and both were geographically dispersed but concentrated in politically pivotal states. Together the industries employed over 2.5 million workers, far more than any other manufacturing sector. ${ }^{63}$ Both industries were traditionally dominated by small- and medium-sized companies, many of them family-owned businesses. The apparel industry was particularly unconcentrated and diffuse, with the average firm employing fewer than fifty-nine workers, operating a single plant, and producing apparel worth less than $\$ 3$ million. ${ }^{64}$ Apparel production was also extremely labor intensive. Textile firms were slightly larger on average and employed more capital, but they were still small and labor intensive compared with U.S. manufacturing as a whole. The industries operated primarily in rural communities in the Southeast and in small urban communities in the Northeast where they were the only major employer in the area. The workers in the industries, most of whom were women and minorities with few skills and little education, had few employment alternatives and were therefore highly resistant to changes that reduced employment in the industry. ${ }^{65}$ Finally, because textile and apparel production requires little capital or technology, the textile and apparel industries were acutely vulnerable to competition from producers in low-wage countries. Although the textile industry was more automated and had greater infrastructure requirements than the apparel industry, it was still highly labor intensive. Moreover, both industries had little involvement in international trade, buying most of their inputs from domestic suppliers. These characteristics indicate that during the immediate postwar period the textile and apparel industries had a high potential benefit of voice and high perceived chance of success, placing them both squarely in the type IV industry category.

During the 1950s, the textile and apparel industries began to face increasing competition from foreign producers. As one of the largest manufacturing employers in the United States, these type IV industries wielded almost unparalleled political power. Thus, when import competition began to cause distress, they turned to the political arena in search of protection. In 1957, the industries won a voluntary restraint agreement on imports from Japan. But even as imports of textiles from Japan leveled off, new entrants into the industry — including Hong Kong, Portugal, India, and Egyptincreased their exports to the United States.

In response to increasing import competition, the textile and apparel industries demanded more comprehensive controls on imports. In 1961, at a conference held under the auspices of GATT, they won a comprehensive Short-Term Arrangement Regarding International Trade in Cotton Textiles, which restricted trade in cotton textiles for one year. This agreement laid the groundwork for the more comprehensive Long-Term Arrangement Regarding International Trade in Cotton Textiles (LTA), which was inaugurated a year later. The agreement permitted importing countries to

63. Bennett and DiLorenzo 1982.

64. See Toyne et al. 1984, 70-84; and Arpan, de la Torre, and Toyne 1982, 3-5.

65. Author's interview with Herman Starobin, research director, International Ladies Garment Workers Union, Washington, D.C., 16 August 1993; see also Women's Wear Daily, 8 October 1991, 18; and Yoffie and Austin 1983, 2-3. 
limit imports on one or a few suppliers, contrary to the most-favored-nation rule of GATT. Although it was initially meant to govern world trade in cotton textiles for only five years, the LTA was extended twice, in 1967 and 1970. Until it finally expired in 1973, the LTA limited the annual growth in the volume of cotton textile exports from developing countries to 5 percent. ${ }^{66}$

These political successes kept the industries' perceived chance of success high. As import competition in synthetic fiber products increased rapidly, however, the potential benefit of voice slowly began to fall. Between 1963 and 1968, imports of cotton apparel grew by only 30 percent, whereas imports of apparel made of synthetic fibers increased 1,700 percent. ${ }^{67}$

When the textile and apparel industries realized that the LTA had not stemmed the tide of textile and apparel imports, they returned to the political arena. Although they failed to win protection from the Tariff Commission in 1969, the textile and apparel industries succeeded in winning another rare exception to the GATT rule of nondiscrimination: the 1973 Multifiber Agreement on Textiles (MFA). Like the LTA, the MFA permitted importing countries to limit imports through bilateral agreements and to impose import limits without compensation in cases of significant market disruption. The MFA-which covered trade in cotton textiles as well as textile products manufactured from cotton, wool, and synthetic fibers-allowed 6 percent annual growth in imports. Successive renewals of the MFA in 1977, 1981, 1986, and 1993 further tightened the regime of quotas, gradually reducing the flexibility of the quotas and the growth rates allowed therein in an effort to reduce the porousness of the agreement.

As a result of their success in obtaining these rare trade concessions, both industries continued to have a relatively high potential benefit of voice and perceived chance of success. When the GATT talks approached in 1978, therefore, the U.S. textile and apparel industries lobbied Congress for exemption from consideration under the GATT framework. Congress responded by passing legislation preventing a reduction in tariffs on textiles and apparel, but the bill was vetoed by President Carter. During the round, tariffs on textiles were reduced from 17 percent to 11.4 percent, and tariffs on apparel were reduced from 25.9 percent to 21.1 percent. ${ }^{68}$ To mollify Congress and the industries, President Carter promised better enforcement of existing protection, a reversal of tariff reductions made during the round if the MFA was not renewed, and a program of Trade Adjustment Assistance.

During the decade after the Tokyo Round tariff cuts were approved, textile and apparel imports rose between two- and threefold (Figure 8). Under severe economic duress, the industries repeatedly sought protection from Congress, but they experienced a series of political defeats at the hands of the Reagan administration. Although the industry succeeded in gaining an exemption from the first Caribbean Basin Initiative (CBI) trade agreement, the second agreement, the Caribbean Basin

66. Yoffie and Austin 1983,3.

67. Loewinger 1982, 6-7.

68. Wolf et al. 1983, 99. 


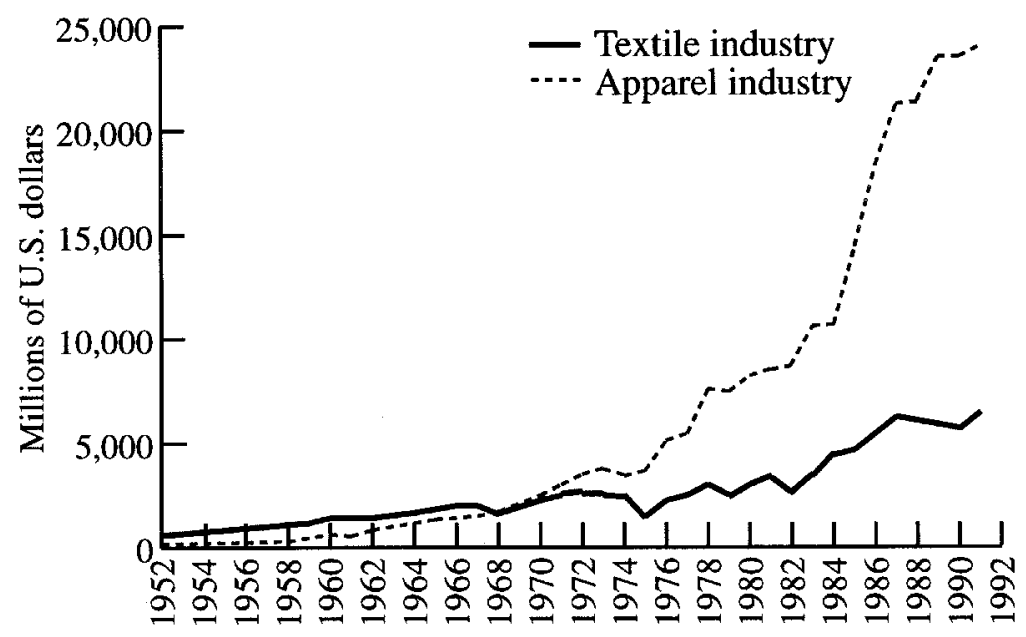

Source: UN Department of International Economic and Social Affairs Statistical Office, 1950-91. The figures for apparel are classified under Standard International Trade Classification (SITC) 841 ("clothing, not of fur") for 1956-63 and under SITC 84 ("clothing") for 1964-91. The figures for textiles are classified under SITC 65 ("textile yarn, fabric, etc.").

FIG URE 8. Imports of textile and apparel products into the United States, 1952-91 (adjusted using an industry-based producer price index)

Textiles Access Program, extended special privileges to textile and apparel producers in the Caribbean, thus leading to a surge of imports into the United States from CBI member countries. In September 1985, the United States and Israel signed a free trade agreement, and in the following year, apparel imports from Israel doubled.

These repeated political failures dealt a blow to the textile and apparel industries. Although their potential benefit of voice remained high, their perceived chance of success began to fall dramatically. As a result, they gradually transformed from highly protectionist type IV industries into type II industries.

The industries' political losses soon translated into economic losses. The imports of textiles and apparel continued to rise dramatically. The MFAs became increasingly ineffective during the 1970s and 1980s because of the soaring value of the dollar, the entry of new Asian producers into the U.S. apparel market, transshipments of semifinished textile products with filled quotas to countries whose quotas were not yet filled, the growing production of apparel made of materials not covered by the agreement, and the efforts of foreign competitors to produce at the cusp of their growing quota limits. Indeed, the nontariff barriers were unable to even slow the rise in apparel imports. With higher capital and technology requirements, the textile industry found the MFA less porous than did the apparel industry. But even it was not 


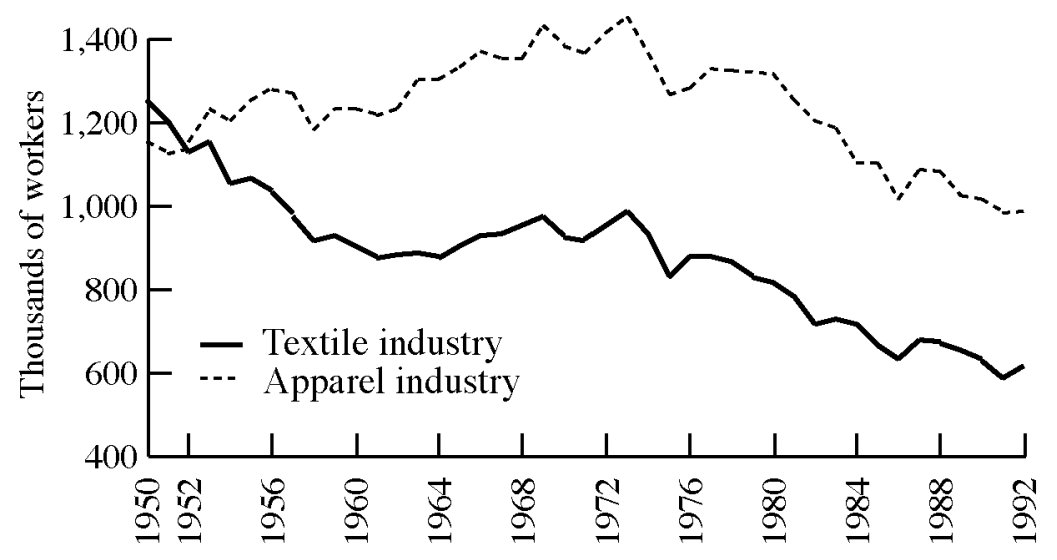

Sources: U.S. Bureau of the Census 1976a, 1991, 1996a.

Note: Data before and after 1972 are not completely comparable due to a minor change in SIC codes

FIGURE 9. Employment in the textile and apparel industries, 1950-92

immune to the problems facing the apparel industry. ${ }^{69}$ Job growth and growth of output in both industries were negative or declining over much of this period. ${ }^{70}$

The high and rising competition from overseas forced the U.S. textile and apparel industries to adjust. The industries responded by downsizing and revitalizing their production processes. The least efficient firms exited the market altogether. Production and exports grew steadily while employment shrank dramatically. Between 1973 and 1992, employment in the apparel industry fell from 1,400,200 to a new low of 985,300 (Figure 9). The drop in the number of textile industry employees was of a similar magnitude (Figure 9). The number of companies in both industries also fell dramatically, especially during the late 1970s and early 1980s (Figure 10). As the most inefficient companies closed, the concentration of the textile and apparel industries increased dramatically, more so in the textile industry than in the apparel industry (Figure 11).

Those firms that remained in the industries sought to improve their ability to compete with foreign producers by investing in new capital and specializing in areas in which they were relatively more competitive. As Figure 12 indicates, the move toward greater capital intensity proceeded at the same rate in the textile and apparel industries. But the magnitude of capital investment in textiles was almost exactly ten times that in apparel, where mechanization proved more difficult. In less than a decade, the textile industry doubled its level of investment in capital. With its high level of

69. Ibid.

70. Hufbauer, Berliner, and Elliott 1986, 140. 


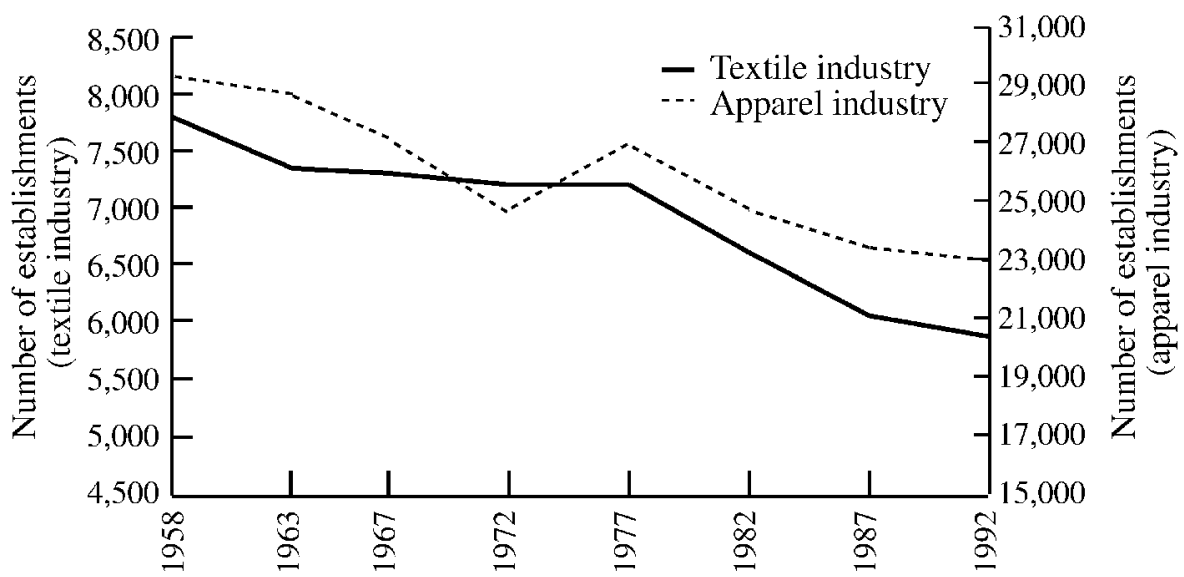

Sources: U.S. Bureau of the Census 1976a, 1991, $1996 \mathrm{a}$.

Note: Data before and after 1972 are not completely comparable due to a minor change in SIC codes.

FIGURE 10. Establishments in the textile and apparel industries, 1958-92

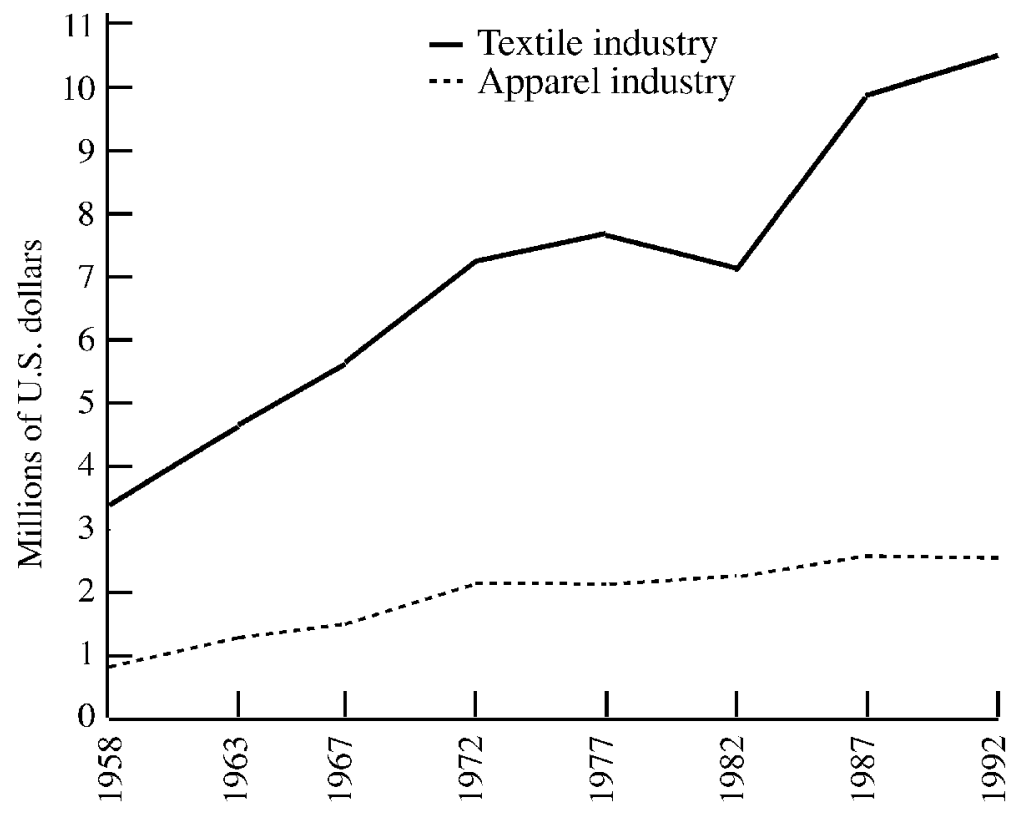

Sources: U.S. Bureau of the Census 1976a, 1991, 1996a.

Note: Data before and after 1972 are not completely comparable due to a minor change in SIC codes.

FIG URE 11. Concentration of the textile and apparel industries, 1958-92 (measured as the value of output per establishment, adjusted using an industry-based producer price index) 


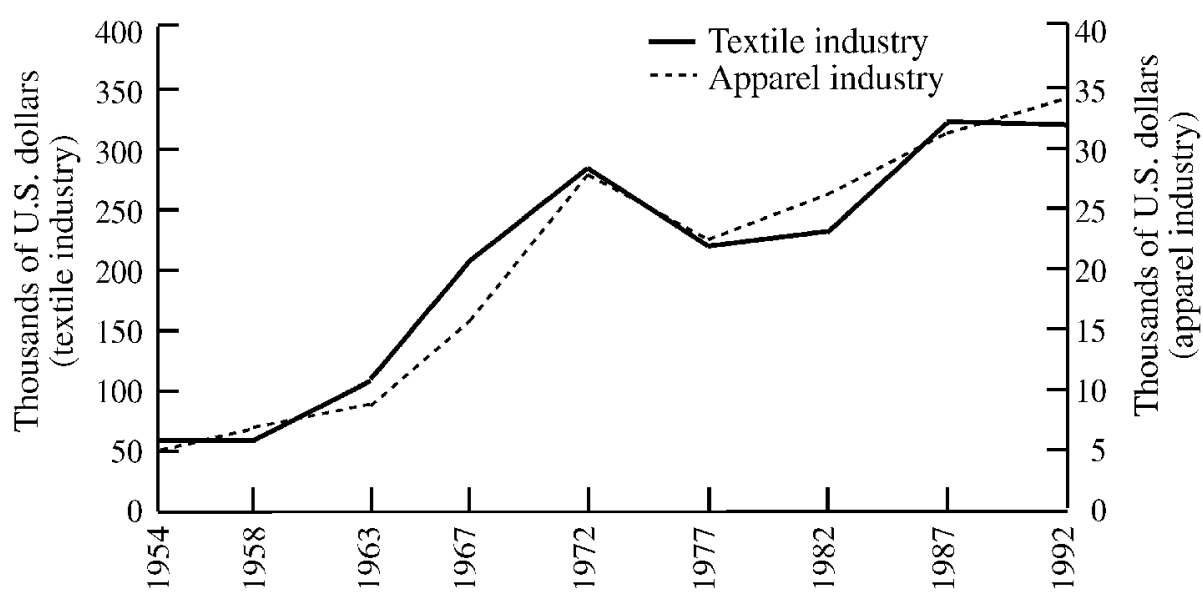

Sources: U.S. Bureau of the Census 1976a, 1991, 1996a.

Note: Data before and after 1972 are not completely comparable due to a minor change in SIC codes.

FIGURE 12. New annual capital investment per establishment in the textile and apparel industries, 1954-92 (measured as the new capital expenditures per establishment, adjusted using an industry-based producer price index)

family ownership, large number of small companies, and limited product lines, the apparel industry found it more difficult to adjust. The production process was not initially amenable to mechanization, and it was not until the mid-1980s that significant improvements in apparel production technology became available to the bulk of the industry. Until the mid-1980s, therefore, new capital investment in apparel lagged far behind that in textiles.

As import competition intensified during the 1970s and 1980s, apparel firms explored the possibility of offshore sourcing to cut costs and maintain competitiveness. They began to take advantage of Section 807 of the Tariff Classification Act of 1962, which allowed U.S. firms to send cut parts overseas for assembly and pay duty only on the value added by the assembly process on reentry of the finished goods. The apparel industry thus moved the most labor-intensive stages of its production processes abroad, and - as Figure 13 demonstrates — both the textile and apparel industries exported more of their products (especially after the value of the dollar began to fall in the late 1980s). ${ }^{71}$ Many apparel firms also began importing finished products from foreign producers to supplement their own product lines and increase their profitability.

In 1985, with import competition growing and the size of their industries shrinking, the textile and apparel industries suffered their greatest political failure to date.

71. See Ghadar, Davidson, and Feigenoff 1987, 74-79; and U.S. Department of Commerce 1993, 32.6. 


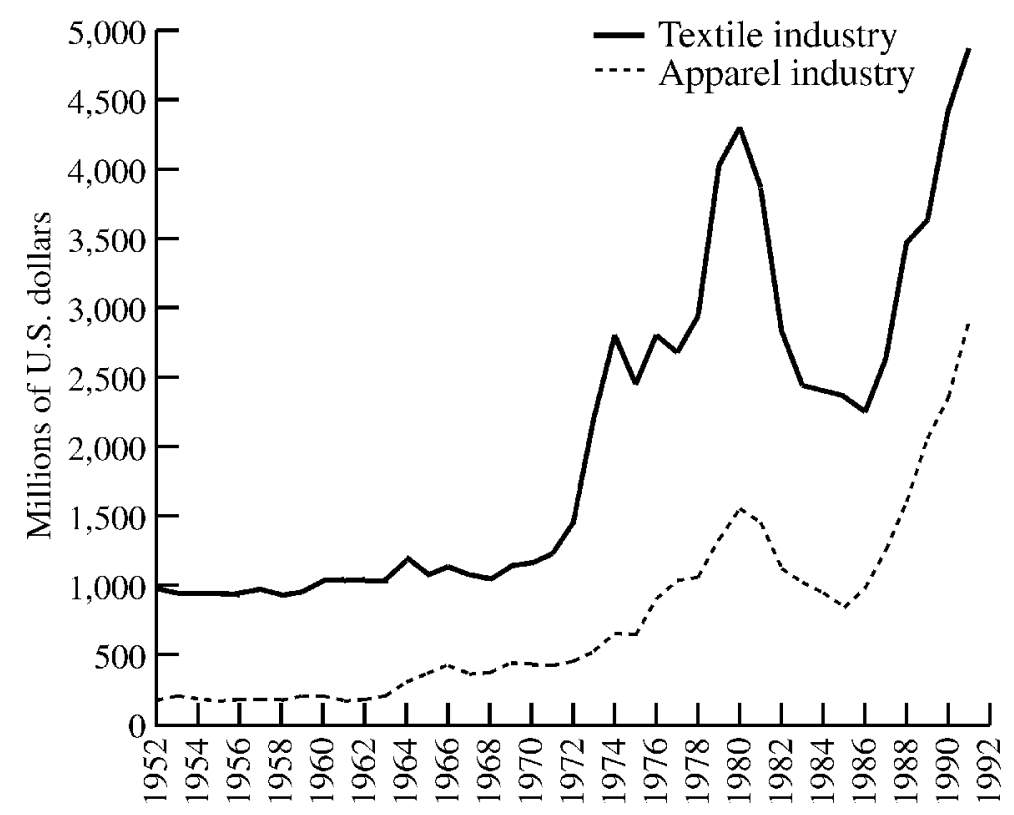

Source: UN Department of International Economic and Social Affairs Statistical Office, 1950-91. The figures before and after 1964 are not completely comparable due to a minor change in SITC codes.

FIGURE 13. Exports of textile and apparel products from the United States, 1952-91 (adjusted using an industry-based producer price index)

The Congressional Textile Caucus proposed a bill to pare back textile imports from the three leading suppliers-Taiwan, South Korea, and Hong Kong-and to place limits on shipments from other major suppliers. For the first time in history, however, the textile and apparel industries faced significant opposition from within their own ranks. Although the bill enjoyed broad support among members of the industries' primary political advocates, the American Apparel Manufacturers Association (AAMA) and the American Textile Manufacturers Institute (ATMI), it faced vocal opposition from members of several newly formed groups representing the retail, import, and export sectors of the industries, most prominently the Retail Industry Trade Action Coalition, the National Retail Merchants Association, the American Retail Federation, and the American Association of Exporters' and Importers' Textiles and Apparel Group. Congress passed the bill, but it was vetoed by President Reagan, and proponents of the bill were not able to muster the votes needed to override the veto. ${ }^{72}$ 
This series of political defeats caused the industries' perceived chance of success to fall dramatically. Both the textile and apparel industries gradually realized that significant new trade barriers were unlikely and that they could only survive by downsizing, specializing, diversifying, and investing in new capital and technology. Consequently, the process of adjustment and restructuring that had begun in the textile and apparel industries in the 1970s accelerated during the 1980s. The Department of Commerce provided financial support for the apparel industry's efforts to create computerized systems that could take over many of the most labor intensive tasks. In the mid-1980s, computerized inventory and ordering networks and CAD and CAM systems created powerful information networks and led to the creation of the "Quick Response" program, which helped domestic apparel firms capitalize on their close proximity to U.S. retailers. ${ }^{73}$ Quick Response soon gained acceptance, and companies began implementing it on an industry-wide scale, with large and mid-sized firms placing greater emphasis on high technology machinery. Smaller firms were reluctant or unable to make the capital investments necessary to become fully involved in Quick Response, however, and many exited the market. This in turn contributed to the increasing concentration of the industry. ${ }^{74}$

As a result of the Quick Response program and increasing trade dependence, the potential benefit of voice for the apparel industry fell dramatically during the 1980s. In the mid-1980s, the AAMA significantly reduced its lobbying activities, and in 1988, it abolished its PAC. In 1989, the AAMA stunned trade policy experts by announcing that it would not support any new legislation to limit textile and apparel imports. $^{75}$

The textile industry did not make such a rapid transition. It had adjusted, but not as drastically as the apparel industry; its potential benefit of voice therefore remained fairly high. During the 1980s, the ATMI reduced its political activities, began to devote more of its resources to export promotion, and stopped filing escape clause petitions. But the organization was not yet willing to give up on the possibility of obtaining trade protection. In 1987, the textile industry joined forces with the footwear industry in an attempt to pass the Textile and Apparel Trade Bill of 1987. For the first time in decades, the ATMI was not joined by the AAMA in its lobbying efforts (the AAMA adopted a neutral position on the bill). The ATMI's efforts were further hindered by the opposition of organizations that represented the interests of importers, exporters, and retailers of textiles and apparel. Congress approved the bill by a wide margin, but it fell shy of the votes needed in the House to override President Reagan's veto. ${ }^{76}$ On the same day that President Reagan vetoed the bill, he signed legislation implementing the Canada Free Trade Agreement, which included

73. Author's interview with Larry Martin, legislative director, American Apparel Manufacturer's Association, Washington, D.C., 12 August 1993; see also Fortune, 27 April 1987, 217.

74. Hammond and Kelly 1990,3-9.

75. Author's interview with Larry Martin.

76. Daily News Record, 9 May 1989, 3. 
provisions to phase out textile and apparel trade barriers between Canada and the United States. The ATMI had vocally opposed the agreement, but the AAMA had again refused to take a formal position. ${ }^{77}$

In 1990, the textile industry made one last effort to obtain comprehensive trade protection. It joined forces with the footwear industry in an effort to pass the Textile Apparel and Footwear Trade Act of 1990, which would have limited increases in imports of textiles and textile products to 1 percent annually. Importers and retailers of textiles and apparel again opposed the bill. Congress approved it by a wide margin, but it failed to gain enough support to overcome a veto.

In 1991, discussions between the governments of the United States, Canada, and Mexico began over the North American Free Trade Agreement (NAFTA). In a report assessing the probable impact of the agreement on the U.S. economy, the ITC concluded that the agreement would benefit the U.S. textile industry because of the agreement's strict rules of origin and would help major U.S. apparel firms compete with East Asian producers. However, the apparel industry as a whole was expected to lose under NAFTA because of increased competition from Mexican producers. Nonetheless, the apparel industry did not oppose NAFTA. Instead, the AAMA worked to gain parity for apparel manufactured in the Caribbean, where many domestic firms had invested. As the legislative director of the AAMA explained: "More of our members are involved in Mexico and the Caribbean. . . . . We would rather see the business go to Mexico or the Caribbean, where we can participate, than to Pakistan, where we can't. The operations in the Caribbean and Mexico lower overall costs and allow us to maintain pretty good employment domestically."78

Thus, by the late 1980s, the transformation of the apparel industry was already beginning to have a positive feedback effect. As NAFTA became law in 1993, the U.S. apparel industry was already making plans for additional investment in Mexico. Apparel firms hoped to incorporate Mexican production plants into the Quick Response program while taking advantage of the lower labor costs to increase the competitiveness of their products. The textile industry also began to experience a positive feedback effect, although of a lesser magnitude, as the previously insular domestic industry began to explore options for export promotion and offshore production in Mexico and the Caribbean.

Soon after Congress approved NAFTA, the member states of GATT concluded the Uruguay Round, which included a ten-year phase-out of the system of quotas provided for by the MFA. The textile industry had opposed the plan in any form. The apparel industry had advocated a fifteen-year phase-out period and a provision that would have linked the reduction of tariffs and quotas to market-opening measures in other countries. Both failed to win any concessions. ${ }^{79}$ Thus, barring a major reversal in policy, barriers to textile and apparel imports will be almost entirely eliminated

77. See Washington Post, 29 September 1988, C1; and Women's Wear Daily, 21 August 1986, 11.

78. Author's interview with Larry Martin.

79. See New York Times, 16 December 1993, D1; and Women's Wear Daily, 8 January 1992, 20. 
within a decade, and the long-standing protectionist trade regime of these manufacturing giants will fade into memory.

Again, the history of the textile and apparel industries provides strong support for the theory of dynamic preferences and strategies. During the immediate postwar period, these industries were type IV industries, and, as import competition increased, they chose voice, as the model predicts. The industries had several major successes in the 1960s and early 1970s, winning a voluntary export restraint agreement and two programs of quantitative import restrictions that were exempted from the GATT nondiscrimination rule. Yet the effectiveness of these trade barriers declined over time as foreign producers found new ways to evade the restrictions and as the effectiveness of the quota program fell. The textile and apparel industries failed to obtain additional protection, and tariffs on textile and apparel imports fell in 1979 after the Tokyo Round of GATT. This set off a new wave of imports and forced the industries to adjust to the more competitive market. Again, the process of adjustment proceeded slowly as a result of the limited availability of technology, labor immobility, and the persistence of significant trade barriers. The textile industry adjusted less than the apparel industry because the nontariff barriers were more effective in preventing imports of textiles than of apparel. Even so, both industries did eventually adjust, and their perceived chance of success and potential benefit of voice fell in response (although it fell less in the textile industry than in the apparel industry). As Table 5 summarizes, the characteristics and political activities of the apparel industry are now closest to those of a type I industry, and the characteristics of the textile industry are closest to those of a type III industry.

\section{Conclusion}

In this article I have developed a theory of dynamic preferences and strategies to explain changes in demand for trade protection by industries over time. I have argued that industry characteristics shape the preferences of industries for free trade or protection in meaningful and predictable ways. My argument suggests that trade liberalization has a positive feedback effect on policy preferences and political strategies of domestic producer groups. As industries adjust to more competitive market conditions, their characteristics change in ways that reduce the likelihood that they will demand protection in the future.

The three case studies provide strong support for the theory. During the immediate postwar period, the footwear, apparel, and textile industries were all highly protectionist. Thus, when import competition increased, the industries demanded protection. Although the industries enjoyed partial success in the political arena during the 1960s and 1970s, they gradually lost trade protection over time as the level and effectiveness of trade barriers fell. This set off a new wave of imports and forced the industries to adjust to their more competitive markets. The process of adjustment proceeded slowly in all three industries because of the limited availability of technology, labor immobility, and the persistence of significant trade barriers. Yet all three 
TABLE 5. Characteristics of the textile and apparel industries prior to, during, and after adjustment

\begin{tabular}{|c|c|c|c|c|c|}
\hline & \multicolumn{2}{|c|}{ Textiles } & \multicolumn{3}{|c|}{ Apparel } \\
\hline & $\begin{array}{c}\text { Pre- } \\
\text { adjustment } \\
\text { (1950-78) }\end{array}$ & $\begin{array}{l}\text { Transition } \\
\text { (1979-94) }\end{array}$ & $\begin{array}{c}\text { Pre- } \\
\text { adjustment } \\
\text { (1950-77) }\end{array}$ & $\begin{array}{l}\text { Transition } \\
(1978-86)\end{array}$ & $\begin{array}{c}\text { Post- } \\
\text { adjustment } \\
\text { (1987-94) }\end{array}$ \\
\hline \multicolumn{6}{|l|}{ Potential benefit } \\
\hline Capital intensity & $M L^{\mathrm{a}, \mathrm{b}}$ & M & $\mathrm{L}$ & ML & M \\
\hline Trade dependence & $\mathrm{L}$ & $\mathrm{L}$ & $\mathrm{L}$ & M & $\mathrm{H}^{\mathrm{c}}$ \\
\hline Factor specificity & $\mathrm{H}$ & $\mathrm{H}$ & $\mathrm{H}$ & M & M \\
\hline \multicolumn{6}{|l|}{ Chance of success } \\
\hline Receptiveness of administration & $\mathrm{H}$ & $\mathrm{L}$ & $\mathrm{H}$ & M & $\mathrm{L}$ \\
\hline Receptiveness of Congress & $\mathrm{H}$ & M & $\mathrm{H}$ & M & M \\
\hline Size of industry & $\mathrm{H}$ & M & $\mathrm{H}$ & M & M \\
\hline Industry distress & $\mathrm{H}$ & $\mathrm{H}$ & $\mathrm{H}$ & $\mathrm{H}$ & $\mathrm{H}$ \\
\hline Past success & $\mathrm{H}$ & $\mathrm{L}$ & $\mathrm{H}$ & $\mathrm{L}$ & $\mathrm{L}$ \\
\hline Approximate type & IV & III & IV & III & I \\
\hline
\end{tabular}

${ }^{\mathrm{a}} \mathrm{L}=$ relatively low.

${ }^{\mathrm{b}} \mathrm{M}=$ average.

${ }^{\mathrm{c}} \mathrm{H}=$ relatively high.

industries did eventually adjust, and their perceived chance of success and potential benefit of voice fell in response. As a result, all three industries have significantly reduced their demand for protection, just as the theory predicts.

The case studies not only establish the plausibility of the theory of dynamic strategies and preferences; they also have broader implications for the study of international political economy and the trade policy process. First, the case studies suggest that, contrary to widely accepted arguments, smaller industries and industries in which output is highly concentrated may not be more likely to organize to demand protection. ${ }^{80}$ The footwear, textile, and apparel industries actually became less willing to organize to press for trade protection as the number of firms fell and the average size of firms increased. This is because the larger firms were better able than their smaller counterparts to invest resources in new capital and more likely to possess the information and resources necessary to operate offshore production and to export goods abroad. Thus, as production became more concentrated in large firms, the willingness of the industry to pursue protection fell. This suggests that as industries grow more concentrated, they may not become more protectionist, because an increase in concentration goes hand in hand with changes in industry characteristics-namely, increased capital intensity and trade dependence- that tend to reduce industry demand for protection. 
The case studies also reveal the central importance of industry organizations in mediating the preferences, strategies, and political activities of an industry. This is important in part because when industry preferences change, formal industry organizations tend to lag behind the industry as a whole. As a result, an industry organization can sometimes continue to demand protection for a short period of time after the industry it represents has adjusted. The lag seems to occur for three primary reasons. First, firms often maintain their membership in industry organizations that no longer accurately represent their preferences because of ingrained ideology, force of habit, or because they want to maintain access to other services offered by the organization. ${ }^{81}$ Second, when firms do leave a protectionist industry organization, they often become politically neutral, rather than joining an organization that presses for free trade. ${ }^{82}$ Third, industry organizations usually maintain financial reserves that allow them to continue their political activities even when membership in the organization and dues collected decline. Over time, however, as firms continue to exit the old organization, it will either be supplanted by an organization that better represents industry views or, as with the FIA and AAMA, bring its position in line with the dominant industry position.

Finally, the case studies demonstrate that some characteristics are more important than others in determining an industry's potential benefit of voice and perceived chance of success. The case studies suggest that two characteristics predominate in industry calculations. An industry cannot be a type IV industry unless it has both a low level of trade dependence and a high past success rate. Conversely, an industry cannot be a type I industry unless it has both a high level of trade dependence and a low past success rate. In essence, the level of trade dependence and the past success rate appear to be necessary, but not sufficient, determinants of industry types.

In addition, the theory of dynamic preferences and strategies has important policy implications. First, the model suggests that government can influence the level of demand for protection by expanding or contracting programs that ease the process of adjustment for import-competing industries. By reducing the costs of adjustment, trade adjustment assistance reduces the potential benefit of voice and thus the likelihood that industries will demand protection. Second, the theory offers a possible resolution to the debate about whether regional trade agreements help or hinder multilateral trade liberalization. Contrary to the prediction that the proliferation of regional trade agreements will lead to the reversal of the historic trend toward freer world trade,$^{83}$ such agreements may actually serve as a first step toward global liberalization by providing greater access to an expanded market and encouraging industries to become more efficient.

Perhaps the most important implication of the theory, however, is that there is "supplier-induced demand" in trade policymaking. According to the theory of dynamic preferences and strategies, an industry's past success rate affects its estimate

81. This lends some support to Olson's suggestion that economic organizations can offer "selective incentives" to induce individuals or firms to join, thereby overcoming the free-rider problem. Ibid., 134.

82. Author's interview with Fawn Evenson.

83. See, for example, Bhagwati 1992; Whalley 1992; Hine 1992; Bhagwati 1991; and Schott 1989. 
of its chance of future success in the political arena. If an industry's success rate has been very low, then its perceived chance of future success is likely to be low as well, and it is much less likely to choose voice when faced with import competition. Thus, restricting the supply of protection today can reduce the demand for protection tomorrow.

The idea of supplier-induced demand suggests that trade protection will be effective in improving the efficiency and competitiveness of sheltered firms only if it is enacted for a limited period of time, with no option for renewal, and if it is accompanied by technical and financial assistance from the government to help ease the process of adjustment. It also suggests a way in which government officials can escape the dilemma created when well-organized, intensely interested industries demand policies that would have a negative aggregate economic effect. ${ }^{84}$ By credibly committing to not respond to industry petitions for protection (thus making the chance of success of voice appear small), policymakers can discourage industries from seeking protection and thereby avoid having to make tough decisions. Indeed, over the last several decades, Congress and the president appear to have done just this by developing institutional devices to reduce the opportunities for logrolling - such as the fasttrack procedure - and by transferring much of the responsibility for deciding trade policy to the executive branch (particularly the ITC), which is generally considered to be less vulnerable to narrow protectionist pressures than Congress.

The dynamic model outlined in this article therefore suggests that policymakers can reduce protectionist sentiment by resisting the momentary pressures for protection that accompany cyclical economic downturns and by creating trade policies that promote the efficiency and competitiveness of U.S. industries. By negotiating further reductions in trade barriers through regional and global trade agreements, enacting only limited trade protection, and providing import-competing industries with technical and financial adjustment assistance, policymakers should be able to reduce demand for protection and thus help to ensure the long-term continuation of free trade.

\section{References}

Aggarwal, Vinod K., Robert O. Keohane, and David B. Yoffie. 1987. The Dynamics of Negotiated Protectionism. American Political Science Review 81:345-66.

American Footwear Industry Association. 1983. Nonrubber Footwear Fact Sheet. Washington, D.C.: AFIA.

Anderson, Kym, and Robert E. Baldwin. 1981. The Political Market for Protection in Industrial Countries: Empirical Evidence. World Bank Staff Working Paper 492. Washington, D.C.: World Bank.

Arpan, Jeffrey S., Jose de la Torre, and Brian Toyne. 1982. The U.S. Apparel Industry: International Challenge, Domestic Response. Atlanta: Georgia State University.

Baldwin, Robert E. 1979. Protectionist Pressures in the United States. In Challenges to a Liberal International Economic Order, edited by Ryan C. Amacher, Gottfried Haberler, and Thomas D. Willett, 223-38. Washington, D.C.: American Enterprise Institute for Public Policy Research.

84. For a discussion of why concentrated interests are more likely to organize than diffuse interests, see Olson 1971. 
1982. The Political Economy of Protectionism. In Import Competition and Response, edited by Jagdish N. Bhagwati, 263-92. Chicago: University of Chicago Press.

. 1985. The Political Economy of U.S. Import Policy. Cambridge, Mass.: The MIT Press.

Robert E. Baldwin, John H. Mutti, and J. David Richardson. 1980. Welfare Effects on the United States of a Significant Multilateral Tariff Reduction. Journal of International Economics 10:405-23.

Bennett, James T., and Thomas J. DiLorenzo. 1982. Import Problems and Public Policies: The U.S. Textile Industry. Backgrounder 192. Washington, D.C.: Heritage Foundation Reports.

Bhagwati, Jagdish. 1988. Protectionism. Cambridge, Mass.: The MIT Press.

1991. Threats to the World Trading Regime: Protectionism, Unfair Trade et al. In International Trade and Global Development, edited by Ad Koekkoek and L. B. M. Mennes, 237-44. New York: Routledge.

1992. Regionalism and Multilateralism: An Overview. Columbia University Discussion Paper Series, 603. New York: Columbia University.

Brock, William A., and Stephen P. Magee. 1978. The Economics of Special Interest Politics: The Case of the Tariff. Decentralization, Bureaucracy, and Government 68:246-50.

- 1980. Tariff Formation in a Democracy. In Current Issues in Commercial Policy and Diplomacy, edited by John Black and Brian Hindley, 1-9. New York: St. Martin's Press.

Burton, Stewart, and David Yoffie. 1986. B-W Footwear. Case No. 9-387-022. Cambridge, Mass.: Harvard Business School.

Cassing, James H., and Arye Hillman. 1986. Shifting Comparative Advantage and Senescent Industry Collapse. American Economic Review 76:516-23.

Cassing, James H., Timothy J. McKeown, and Jack Ochs. 1986. The Political Economy of the Tariff Cycle. American Political Science Review 80:843-62.

Caves, Richard E., and Michael E. Porter. 1976. Barriers to Exit. In Essays on Industrial Organization in Honor of Joe S. Bain, edited by Robert T. Masson and P. David Qualls, 39-69. Cambridge, Mass.: Ballinger Publishing Co.

Conybeare, John A. C. 1991. Voting for Protection: An Electoral Model of Tariff Policy. International Organization 45:57-81.

Darnay, Arsen J., ed. 1994. Economic Indicators Handbook. Washington, D.C.: Gale Research.

Destler, I. M. 1986. American Trade Politics: System Under Stress. Washington, D.C.: Institute for International Economics.

Finger, J. M., H. Keith Hall, and Douglas R. Nelson. 1982. The Political Economy of Administered Protection. American Economic Review 72:452-66.

Frey, Bruno S. 1984. The Public Choice View of International Political Economy. International Organization 38:199-223.

Frieden, Jeffry A. 1991. Modern Political Economy and Latin America, 1965-1985. Princeton, N.J.: Princeton University Press.

Ghadar, Fariborz, William H. Davidson, and Charles S. Feigenoff. 1987. U.S. Industrial Competitiveness: The Case of Textile and Apparel. Lexington, Mass.: Lexington Books.

Hammond, Janice H., and Maura G. Kelly. 1990. Quick Response in the Apparel Industry. Case Study 9-690-038. Cambridge, Mass.: Harvard Business School.

Hansen, Wendy L. 1990. The International Trade Commission and the Politics of Protectionism. American Political Science Review 84:21-46.

Hansen, Wendy L., and Thomas J. Prusa. 1995. The Road Most Taken: The Rise of Title VII Protection. World Economy 18:295-313.

Helleiner, G. K. 1991. Transnational Enterprises and the New Political Economy of U.S. Trade Policy. In International Political Economy, edited by Jeffry A. Frieden and David A. Lake, 353-61. New York: St. Martin's Press.

Hine, Robert C. 1992. Regionalism and the Integration of the World Economy. Journal of Common Market Studies 30:119-23.

Hirschman, Albert O. 1970. Exit, Voice, and Loyalty: Responses to Decline in Firms, Organizations, and States. Cambridge, Mass.: Harvard University Press. 
Hufbauer, Gary Clyde, Diane T. Berliner, and Kimberly Ann Elliott. 1986. Trade Protection in the United States: 31 Case Studies. Washington, D.C.: Institute for International Economics.

Krasner, Stephen, ed. 1982. International Regimes. International Organization 36 (spring). Special issue. Keohane, Robert. 1984. After Hegemony: Cooperation and Discord in the World Political Economy. Princeton, N.J.: Princeton University Press.

Krueger, Anne O. 1992. Political Economy, International Trade, and Economic Integration. American Economic Review 82:109-14.

Lake, David. 1983. International Economic Structures and American Foreign Economic Policy. World Politics 35:517-43.

Lavergne, Real P. 1983. The Political Economy of U.S. Tariffs. New York: Academic Press.

Loewinger, Andrew. 1982. Textile Trade. In U.S. International Economic Policy 1981: A Draft Report, edited by Gary Clyde Hufbauer, 2-1-2-36. Washington, D.C.: International Law Institute.

Lutz, James M. 1991. Determinants of Protectionist Attitudes in the United States House of Representatives. International Trade Journal 5:301-28.

Magee, Stephen P. 1980. Three Simple Tests of the Stolper-Samuelson Theorem. In Issues in International Economics, edited by Peter Oppenheimer, 138-53. Boston: Oriel Press.

Mayer, Wolfgang. 1984. Endogenous Tariff Formation. American Economic Review 74:970-85.

Milner, Helen. 1988. Resisting Protectionism: Global Industries and the Politics of International Trade. Princeton, N.J.: Princeton University Press.

Morici, Peter, and Laura L. Megna. 1983. U.S. Economic Policies Affecting Industrial Trade: A Quantitative Assessment. Washington, D.C.: National Planning Association.

Olson, Mancur. 1971. The Logic of Collective Action: Public Goods and the Theory of Groups. Cambridge, Mass.: Harvard University Press.

Organization for Economic Cooperation and Development. 1976. The Footwear Industry. Paris: OECD.

Pearson, Charles. 1983. Emergency Protection in the Footwear Industry. Thames Essay 6. London: Trade Policy Research Center.

Pincus, J. J. 1975. Pressure Groups and the Pattern of Tariffs. Journal of Political Economy 83:757-78.

Ray, Edward John. 1981. The Determinants of Tariff and Nontariff Trade Restrictions in the United States. Journal of Political Economy 89:105-21.

Riker, William H. 1988. Liberalism Against Populism. Prospect Heights, Ill.: Waveland Press.

Riker, William H., Kenneth A. Shepsle, and Arthur Denzau. 1985. Farquharson and Fenno: Sophisticated Voting and Home Style. American Political Science Review 79:1118-34.

Rogowski, Ronald. 1987a. Political Cleavages and Changing Exposure to Trade. American Political Science Review 81:1121-37.

1987b. Trade and the Variety of Democratic Institutions. International Organization 41:203-23. 1989. Commerce and Coalitions. Princeton, N.J.: Princeton University Press.

Schott, Jeffry, ed. 1989. Free Trade Areas and U.S. Trade Policy. Washington, D.C.: Institute for International Economics.

Staiger, Robert W., and Frank A. Wolak. 1994. Measuring Industry-Specific Protection: Antidumping in the United States. In Brookings Papers on Economic Activity: Microeconomics 1994, edited by Martin Neil Baily, Peter C. Reiss, and Clifford Winston, 51-103. Washington, D.C.: Brookings Institution.

Szenberg, M., J. W. Lombardi, and E. Y. Lee. 1977. Welfare Effects of Trade Restrictions. New York: Academic Press.

Tacaks, Wendy. 1981. Pressures for Protectionism: An Empirical Analysis. Economic Inquiry 19:687-93. Toyne, Brian, Jeffrey S. Arpan, David A. Ricks, and Terence A. Shimp. 1984. The Global Textile Industry. London: George Allen and Unwin.

UN Department of International Economic and Social Affairs Statistical Office. 1950-91. Yearbook of International Trade Statistics. Vol. I. Trade by Country. New York: United Nations.

U.S. Bureau of the Census. 1971. 1967 Census of Manufacturers. Vol. 2. Industry Statistics, Part 2. SIC Major Groups 25-33. Washington, D.C.: U.S. Government Printing Office.

. 1976a. 1972 Census of Manufacturers. Vol. 2. Industry Statistics, Part 1. SIC Major Groups 20-26. Washington, D.C.: U.S. Government Printing Office. 
1976b. 1972 Census of Manufacturers. Vol. 2. Industry Statistics, Part 2. SIC Major Groups 27-34. Washington, D.C.: U.S. Government Printing Office.

- 1990. 1987 Census of Manufacturers. Industry Series. Tanning; Industrial Leather Goods; and Shoes. Washington, D.C.: U.S. Government Printing Office.

1991. 1987 Census of Manufacturers. Subject Series. General Summary. Washington, D.C.: U.S. Government Printing Office.

— 1996a. 1992 Census of Manufacturers. Historical Industry Statistics. Washington, D.C.: U.S. Government Printing Office.

_. 1996b. 1992 Census of Manufacturers. Final Industry Series. General Statistics. Washington, D.C.: U.S. Government Printing Office.

U.S. Department of Commerce. 1977. 1972 Enterprise Statistics. Washington, D.C.: U.S. Government Printing Office.

—. 1979a. U.S. Commodity Exports and Imports, 1976/75. Washington, D.C.: U.S. Government Printing Office.

. 1979b. U.S. Commodity Exports and Imports as Related to Output, 1976/75. Washington, D.C.: U.S. Government Printing Office.

- 1981. 1977 Enterprise Statistics. Washington, D.C.: GPO.

1982a. U.S. Commodity Exports and Imports, 1977/6. Washington, D.C.: U.S. Government Printing Office.

- 1982b. U.S. Commodity Exports and Imports as Related to Output, 1977П6. Washington, D.C.:

U.S. Government Printing Office.

- 1993. U.S. Industrial Outlook 1993. Washington, D.C.: U.S. Government Printing Office.

1994. U.S. Industrial Outlook 1994. Washington, D.C.: U.S. Government Printing Office.

U.S. International Trade Commission (USITC). 1976a. Footwear Investigation No. 758. Washington, D.C.: USITC.

1976b. Report to the President on Investigation No. TA-201-7 Under Section 201 of the Trade Act of 1974. USITC Publication 758. Washington, D.C.: USITC.

1977. Report to the President on Investigation No. TA-201-18 Under Section 201 of the Trade Act of 1974. USITC Publication 799. Washington, D.C.: USITC.

1981. Report to the President on Investigation No. TA-203-7 Under Section 203 of the Trade Act of 1974. USITC Publication 1139. Washington, D.C.: USITC.

Whalley, John. 1992. CUSTA and NAFTA: Can WHFTA Be Far Behind? Journal of Common Market Studies 30:125-41.

Wolf, Martin, Hans Hinrich Gilsmann, Joseph Pelzman, and Dean Spinanger. 1983. Costs of Protecting Jobs in Textile and Clothing. Thames Essay 37. London: Trade Policy Research Centre.

Yoffie, David B. 1983a. Adjustment in the Footwear Industry. In American Industry in International Competition, edited by John Zysman and Laura Tyson, 313-49. Ithaca, N.Y.: Cornell University Press.

- 1983b. Power and Protectionism: Strategies of the Newly Industrializing Countries. New York: Columbia University Press.

Yoffie, David B., and Jane Kenney Austin. 1983. Textiles and the Multi-fiber Agreement. Case Study 383-164. Cambridge, Mass.: Harvard Business School.

Yoffie, David B., and Joseph L. Badaracco, Jr. 1984. Rational Models of Corporate Political Strategies. Working Paper 9-785-018. Cambridge, Mass.: Harvard Business School. 